\title{
Musical and Cultural Perspectives of Héctor Campos Parsi: An examination of his influences and analysis of selected vocal works
}

Cynthia Ortiz-Bartley

West Virginia University, cynthiaortizmusic@gmail.com

Follow this and additional works at: https://researchrepository.wvu.edu/etd

Part of the Music Education Commons, and the Music Performance Commons

\section{Recommended Citation}

Ortiz-Bartley, Cynthia, "Musical and Cultural Perspectives of Héctor Campos Parsi: An examination of his influences and analysis of selected vocal works" (2019). Graduate Theses, Dissertations, and Problem Reports. 7372.

https://researchrepository.wvu.edu/etd/7372

This Dissertation is protected by copyright and/or related rights. It has been brought to you by the The Research Repository @ WVU with permission from the rights-holder(s). You are free to use this Dissertation in any way that is permitted by the copyright and related rights legislation that applies to your use. For other uses you must obtain permission from the rights-holder(s) directly, unless additional rights are indicated by a Creative Commons license in the record and/ or on the work itself. This Dissertation has been accepted for inclusion in WVU Graduate Theses, Dissertations, and Problem Reports collection by an authorized administrator of The Research Repository @ WVU.

For more information, please contact researchrepository@mail.wvu.edu. 
Musical and Cultural Perspectives of Héctor Campos Parsi:

An examination of his influences and analysis of selected vocal works

\title{
Cynthia Ortiz
}

\author{
Dissertation submitted \\ to the College of Creative Arts \\ at West Virginia University \\ In partial fulfillment of the requirements for the degree of \\ Doctor of Musical Arts in \\ Voice Performance
}
Hope Koehler, D.M.A., Chair
Lee Blair, M.F.A.
Matthew Heap Ph.D.
William Koehler, D.M.A.

School of Music
Morgantown, West Virginia
2019

Keywords: Puerto Rican art song, music enculturation, Héctor Campos Parsi

Copyright 2019 Cynthia Ortiz 


\begin{abstract}
Musical and Cultural Perspectives of Héctor Campos Parsi:

An examination of his influences and analysis of selected vocal works
\end{abstract}

\title{
Cynthia Ortiz
}

This paper examines the historical and cultural atmosphere in Puerto Rico and how it affected one of Puerto Rico's most celebrated composers, Héctor Campos Parsi, and two selected works in two different times of his life. The discussion includes events that affected the island with respect to art music from 1898, the birth of Héctor Campos Parsi in 1922, and up to 1986, which marks the date of the second selected work. This document considers three questions about cultural and structural influences about the life and experiences of Héctor Campos Parsi: Does a composer's life experience and environment and culture shape their musical output? What are the influences of environmental factors, such as politics, economy, social, and musical culture in Puerto Rico from 1898 to 1986, the latter year marking the second composition under analysis in this paper? Who were the primary and foremost cultural and musical influences on Héctor Campos Parsi? This document offers an analysis of two song cycles, Canciones de Cielo y Agua for soprano or tenor and piano and Sonetos Sagrados for soprano and wind ensemble, that best capture his personal style or sound before and after his studies with Nadia Boulanger. It also examines the musical climate as well as the nationalist and populist political issues affecting Puerto Rican composers as a result of political and social issues, which may have influenced the decisions made by Héctor Campos Parsi as a composer. 


\section{TABLE OF CONTENTS}

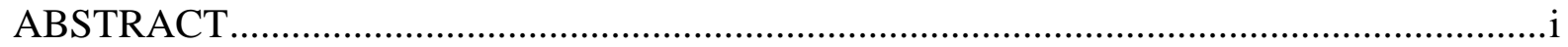

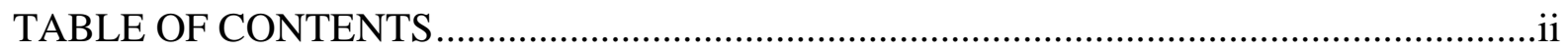

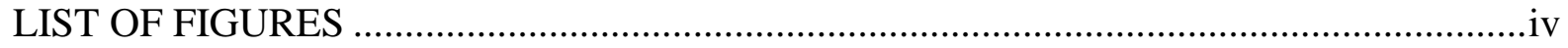

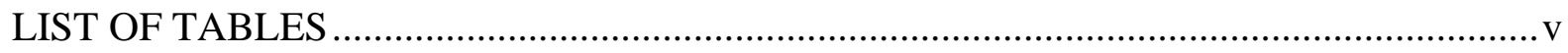

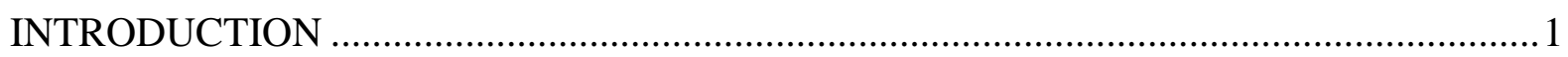

LITERATURE REVIEW ..................................................................................

CHAPTER 1: THE CULTURAL ENVIRONMENT OF PUERTO RICO AFTER 1898: MUSIC,

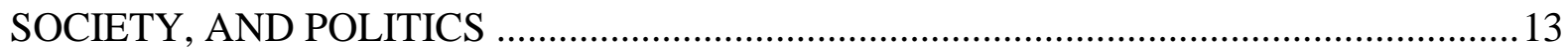

CHAPTER 2: HECTOR CAMPOS PARSI'S MUSICAL LIFE - EDUCAION, INFLUENCE,

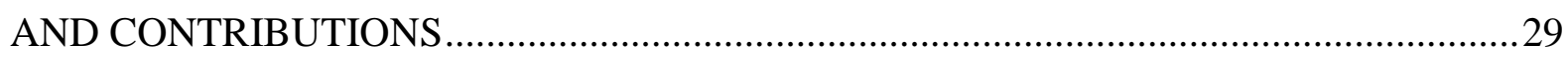

CHAPTER 3: SONG ANALYSIS AND TRANSLATIONS .......................................... 40

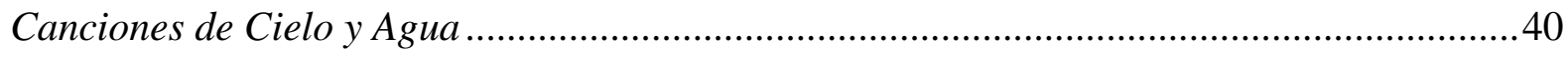

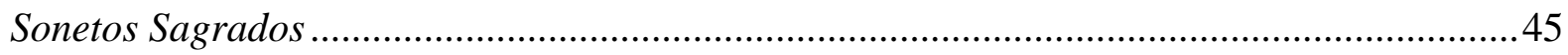

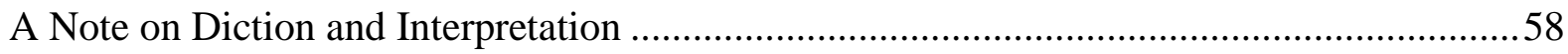

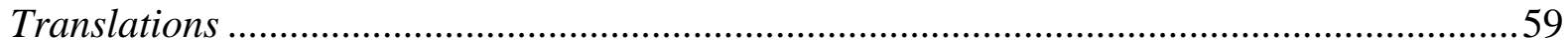

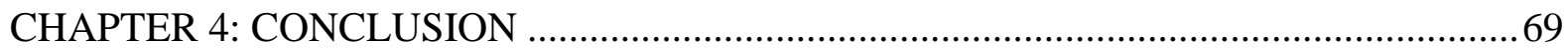

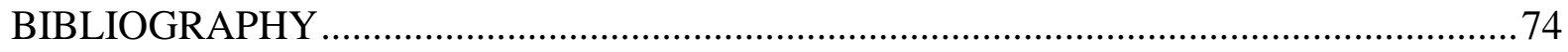




\section{LIST OF FIGURES}

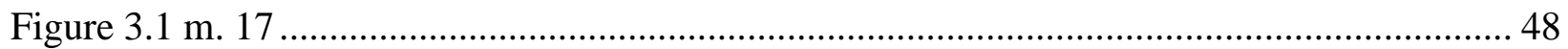

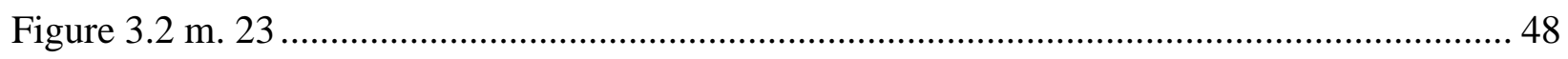

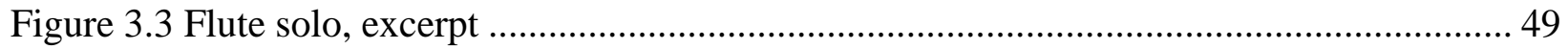

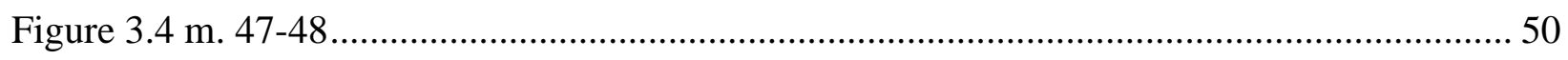

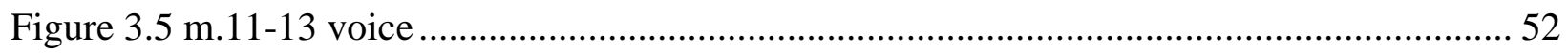

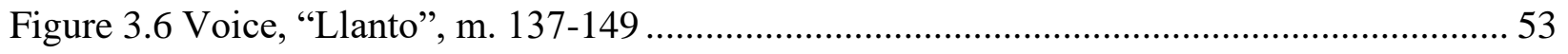

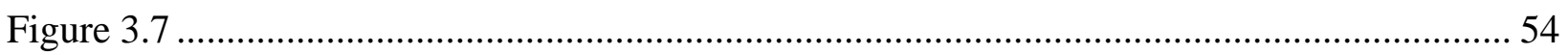




\section{LIST OF TABLES}



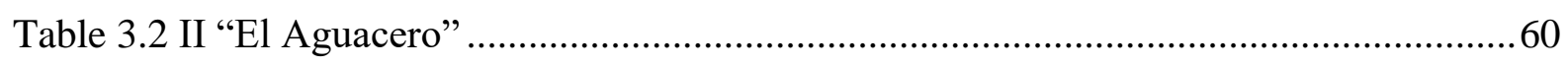

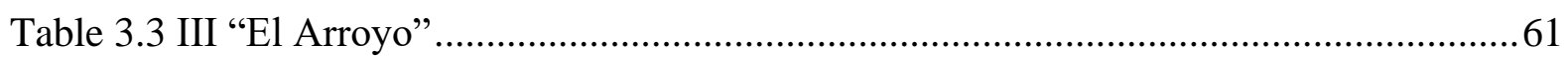

Table 3.4 I. "No me mueve, ni Dios" (Attributed to St. Theresa of Avila) ............................63

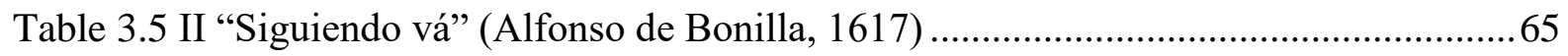

Table 3.6 III. "O dulces prendas” (Sebastián de Córdoba, 1505) ........................................66

Table 3.7 IV. "Contento, amor y paz” (Gregorio Silvestre, 1502) .....................................67

Table 3.8 V. “Levánta y despierta” (Gregorio Silvestre, 1502).......................................... 68 


\section{INTRODUCTION}

This paper will examine the influences from the history and culture of Puerto Rico on one of its most celebrated composers, Héctor Campos Parsi. This will include an examination of two selected works in two different periods of his life. The discussion will include events that affected the island with respect to art music from 1898, the birth of Héctor Campos Parsi, and up to 1986 , which marks the date of the second selected work. The focus of this examination will be primarily on his life experiences, such as his music education, environment and culture that shaped the composer's musical output and his involvement as a Puerto Rican Nationalist composer. This is followed by supplemental discussions based on specific environmental, political, and social issues on the island that affected his musical style.

It is my intent to analyze two song cycles that best capture his personal style before and after his studies with Nadia Boulanger and to provide poetic and word for word translations of the text. Canciones de Cielo y Agua, unlike Sonetos Sagrados, was composed in 1947 after he left Puerto Rico to study composition. It is one of his first major vocal compositions. This work of three songs gives a performer the opportunity to perform a work that was not influenced by more modern composition education. This song cycle is free from influences from his formal training which he received later in the United States and in France. As a result, it provides a basis for comparison to Sonetos Sagrados, published in 1986, which is a contemporary composition that incorporates a modern compositional style. These five songs contain elements of both contemporary writing and influence from Puerto Rican and Spanish cultural expression.

His time with Aaron Copland and Nadia Boulanger allowed Campos Parsi to express his unique voice with a strong foundation in composition, counterpoint, harmony, form, and analysis 
as well as ear training. His experience studying outside of Puerto Rico was socially and politically relevant because other islanders did not have the same advantages to study abroad under the new government of the United States as they did when Spain ruled Puerto Rico, particularly if they were of the working class. Héctor Campos Parsi is tied to discussions of Nationalism, but his music was also a product of cultural changes and formal music education. Culture and education may have been factors in his compositional style.

One of the cultural terms in this paper is transculturation, which is a convergence of cultures that can cause a conquered colony, for example, to lose some or most of its identity. The term was introduced to the field of anthropology by Cuban anthropologist, Fernando Ortiz, in 1947, which coincides with the composition date of Canciones de Cielo y Agua as well as the industrialization effort of the United States known as Operation Bootstrap in the 1940s. It is also important to examine the musical climate as well as the nationalist and populist political issues affecting Puerto Rican composers as a result of political and social issues, which may have influenced the decisions made by Héctor Campos Parsi as a composer. This would include any issues, events, or cultural changes that may have occurred in his childhood years.

One of my personal goals for my final research paper is to encourage readers - voice teachers and singers in particular - to accept this repertoire as part of the standard repertoire for undergraduate and graduate voice students. Our standard current voice programs skip over most of the contributions of Spanish language art songs, particularly from Latin American art song composers. This acceptance means expanding the study of diction to include Spanish and therefore, Spanish language vocal literature from various countries, as a standard course offering, with equal weight of relevance as French, Italian, and German art song literature, diction, and 
history. While this paper would only cover the music of one Puerto Rican composer, it could serve as a template for examining the works of other Latino and Iberian composers.

This paper is divided into four chapters plus a review of the literature. Chapter one looks at the environmental, historical, and musical events that occurred from 1898-1922, which marks the US takeover to the birth of Héctor Campos Parsi. Chapter two follows the composer from birth until his departure to the US, his years of study outside of Puerto Rico, and his return to Puerto Rico until 1986, the date of the second composition under analysis. These chapters will discuss Héctor Campos Parsi's musical life with respect to his education, influence, and extramusical contributions. Chapter three examines two vocal works from different periods of his life: Canciones de Cielo y Agua (1947) and Sonetos Sagrados (1986). The final chapter summarizes the findings in this paper with conclusions on Puerto Rican culture and cultural influence on the composer, and thoughts for further study.

\section{LITERATURE REVIEW}

In a 1984 New York Times article by Donal Henahan “Music View: Does A Composer’s Life Affect His Music?", the author argues against the standard musicological view that the life of the composer is irrelevant ${ }^{1}$. Henahan believed that a composer's biography may lead us to a better understanding of the work itself. This paper will address influences that include cultural and personal life experiences of the composer. In order to explore the topic of cultural and environmental influences on Héctor Campos Parsi as a Puerto Rican composer, the following literature was selected by basis of relevance to answer the following questions:

1. Donal Henahan, "Music View: Does A Composer's Life Affect His Music?" The New York Times, February 19, 1984, Section 2, 19. https://www.nytimes.com/1984/02/19/arts/musicview-does-a-composer-s-life-affect-his-music.html 
1. Does a composer's life experience and environment and culture shape their musical output?

2. What is the conversation regarding environmental factors, such as politics, economy, social, and musical culture in Puerto Rico from 1898 to 1986, the latter year marking the second composition under analysis in this paper?

3. Who were the primary and foremost cultural and musical influences on Héctor Campos Parsi?

I use these questions as a heading to organize my literature review. This review focuses on the discussion of influence on musical output, and the cultural and environmental factors that make up that group of influence. These factors include historical, political, social, economic, cultural events and people, which are presented in peer-reviewed journal articles, historical accounts, interview material, translated articles from Puerto Rico's authors on music, the most cited biographical dissertation with interviews of the composer by the author, and research on the effects of culture.

The sources for this paper include reviews of literature on Héctor Campos Parsi, music in Puerto Rico, Puerto Rican history, nationalism, enculturation, and includes source types such as journal articles, websites considered primary sources, an interview with Héctor Campos Parsi, the collections and links to literature through the Instituto de Cultura Puertorriquena (Institute of Puerto Rican Culture), dissertations on the composer, and musical scores.

The relevant articles discussing culture provided support for how culture shapes an individual via politics, economy, historical events, religion, and the arts. The terms that apply to the focus of this paper include terminology such as: culture, cultural identity, memetics, transculturation, and enculturation. The views of music critics and musicians from the island 
acknowledge the social, political, and cultural effects on music in Puerto Rico particularly as it concerns Puerto Rican identity and nationalism.

Academic journal articles, literature by composers, music critics, and the composer himself, as well as music historians serving as primary sources provide historical details that depict the Puerto Rican musical culture. La Gran Enciclopedia de Puerto Rico, Volume 7: Música en Puerto Rico, 1976, with Campos Parsi listed as the author, is an encyclopedic volume of music in Puerto Rico. The Institute of Puerto Rican Culture or Instituto de Cultura Puertorriqueña was also a major source with numerous links to archival records, articles, musical examples, and historical imagery.

Does a composer's life experience and environment and culture shape their musical output?

Culture is a combination of society, politics, religion, and the arts. The following articles answer the question if it is possible for these cultural and environmental factors to affect or shape someone's work, particularly if that work is musical as in the case of Campos Parsi. This topic is mostly found in articles associated with the field of ethnomusicology as it involves the study of someone's culture as well as their music. Some of these articles are also in the field of research in music education, which provide quantitative data. In conjunction with articles associated with ethnomusicology there are discussions of the anthropology of music as it is a combined lens of anthropology and musicology.

From early childhood, children acquire an understanding of harmonic language by the age of four or five. This solved the point of study for authors Corrigall and Trainor in Musical Enculturation in Preschool Children Acquisition of Key and Harmonic Knowledge. They also found that children anticipated and understood Western harmonic functions as a result of early 
childhood exposure to Western music. Similarly, "conscious and unconscious acquisition" of cultural knowledge is the basis of enculturation and is the foundation of an individual's musical expression. ${ }^{2}$ The authors of "Enculturation Effects in Music Cognition: The Role of Age and Music Complexity", discuss how "enculturation affects one's understanding of music structure before adulthood." The findings suggest that children and adults will remember what is familiar from their own culture, particularly that of the home. The authors also concluded that children and adults will possess a preference to music from their own culture. ${ }^{3}$ These are useful methods to examine the influences of a composer or their writing style.

In the 2018 chapter titled, "The Relationship Between Music, Culture, and Society", Georgina Barton explores the literature of scholars in the field of culture studies and connects that to music and culture. The author uses these sources to support her argument that while society, culture, and music may seem separate, they are "inextricably linked", and how they are connected. She cites the work of prominent scholars associated with ethnomusicology such as Bruno Nettl, Alan Lomax, and Alan P. Merriam (Barton, Introduction) ${ }^{4}$. This article supplements the perspective of this paper, such that the composer's output and environmental factors are also connected.

2. Kathleen A.Corrigall, and Laurel J. Trainor. "Musical Enculturation in Preschool Children: Acquisition of Key and Harmonic Knowledge." Music Perception: An Interdisciplinary Journal 28, no. 2 (December 2010), 195-196.

3. Steven J. Morrison, Steven M. Demorest, and Laura A. Stambaugh. "Enculturation Effects in Music Cognition: The Role of Age and Music Complexity." Journal of Research in Music Education 56, no. 2 (2008): 118-126. www.jstor.org/stable/40343719

4 Georgina Barton, "The Relationship Between Music, Culture, and Society: Meaning in Music: Implications for Classroom Practice.” (August 14, 2018): 1. https://link.springer.com/chapter/10.1007/978-3-319-95408-0_2. 
Patrick George's Western Classical Music Development: a statistical analysis of composers similarity, differentiation and evolution (2017), offers a statistical perspective suggesting that composers "overall development is not due to simple creative genius alone, but to the influence of past masters and genres, as constrained or facilitated by the cultural conditions of time and place." He examines literature supporting his premise that memes, the unit of cultural information, are passed along in an evolutionary process. ${ }^{5}$ Comparatively, The Memetics of Music by Steven Jan discusses an interdisciplinary approach to culture, for example in musicology, along the lines of evolutionary biology. He describes a process that may support the way a composer's style is as a result of culture, not his own uniqueness. The author states, "From the point of view of the composer, learning the craft of composition generally involves learning how to manipulate such standard patterns and figures; and even when the composer discovers his or her distinctive 'voice', there is perhaps more that is borrowed (albeit transformed) than is genuinely new in his or her own style". ${ }^{6}$

In his interview with Gustavo Batista on May 23, 1984, Campos Parsi said that his interest in music may have been from family influence or congénito. He said that he was not sure when this interest actually began, except that this was not a casual experience. His home life consisted of trained musicians that played both informally and professionally. His mother played the harp, his father played the piano, particularly Beethoven sonatas, as well as his aunt, uncle, grandfather and uncle. While his mother and father were trained musicians by reputable island

5. Patrick Georges, Western Classical Music Development: a statistical analysis of composer's similarity, differentiation and evolution. (2017) Scientometrics, 112 (1): 21.

6. Steven Jan, The Memetics of Music: A Neo-Darwinian View of Musical Structure and Culture. (New York: Routledge, 2016), 1. 
musicians, his father's love of art music and active participation instilled in Campos Parsi a love and appreciation for music of the island and from Europe. ${ }^{7}$

What is the conversation regarding environmental factors, such as history, politics, economy, social, and musical culture in Puerto Rico after 1898 ?

Kal Wagenheim and Olga Jiménez de Wagenheim compiled an invaluable, extensive collection of letters and articles from many historical sources including "Spanish clergy and colonial governors, men of letters, farmers, slum dwellers, politicians (Puerto Rican and American) and journalists of varying opinion". They wanted to capture the essence of the people and the zeitgeist of the event being described. This anthology is rich with information of events from the initial discovery of the island by Columbus and its inhabitants to the last article written in 1990. The book is divided into ten sections with a total of 76 articles of historical accounts, many of them first-hand accounts that have been translated into English. Some of the articles highlight the culture as it existed during the events that took place after the Spanish-American War. ${ }^{8}$

In Catherine Dower's book, Puerto Rican Music Following the Spanish-American War: 1898, the Aftermath of the Spanish-American War and Its Influence on the Musical Culture of Puerto Rico, 1983, the author makes a case that Puerto Rico's musical life continued after the war. The author presents "a survey of the cultural activities" that happened in Puerto Rico after the US took the island from Spain following the Spanish-American War. She discussed what was happening on the island in the $19^{\text {th }}$ century, the assumed regression of the economy and culture,

7. Gustavo Batista, Entrevista a Héctor Campos Parsi, (September 12, 1984). Accessed August 10, 2019, http://www.gustavobatista.com/entrevista/hector_campos_parsi.pdf 8. Kal Wagenheim, and Olga Jimenez de Wagenheim, Puerto Rico: A Documentary History. $5^{\text {th }}$ ed. (Markus Wiener Publishers: Princeton, NY, 1999), xi. 
the US arrival, music education, new political leadership and government structure, musical activities in specific locations on the island such as the Ateneo Puertorriqueño, and highlighted significant $19^{\text {th }}$ and $20^{\text {th }}$ century composers and institutions. ${ }^{9}$

She stated that Puerto Rico was thought to have experienced a decline in its quantity of performances and musical contributions in the absence of Spain's dominance. According to Dower's summation of Fernando Callejo Ferrer's 1971 study, Música y Músicos

Portorriqueños ${ }^{10}$, some opera companies, for example, wavered in their commitment to coming to Puerto Rico because the island had experienced an economic depression. This may have been one of the events that contributed to a lack of musical growth and innovative expression.

However, the author argues that researchers have neglected the growth that occurred during that time as a result of specific composers such as Fernando Callejo Ferrer himself. Musicians from military bands and opera companies that decided to come to the island to perform became the music teachers of the island and their musical culture continued to grow. ${ }^{11}$

Donald Thompsons is an acknowledged, well-published scholar who is responsible for Music in Puerto Rico: A Reader's Anthology (2002). The author provides an anthology of literature, much of it translated from the original sources and similar to the structure of the Wagenheim and Wagenheim's sourcebook. In 2002 Thompson's book, Music in Puerto Rico, the author presents writings from the Spanish in 1495 and ends with an article by a well-known music critic written in 1997, Sylvia Lamoutte. These articles discuss the Puerto Rican danza, art

9. Catherine Dower, Puerto Rican Music Following the Spanish-American War: 1898, the Aftermath of the Spanish-American War and Its Influence on the Musical Culture of Puerto Rico. (Landham, Md: University of America Press, 1983), iii-v.

3. It is not uncommon to find publications from this 1971 or earlier that contain the term Portorriqueños. Future literature will update the term to Puertorriqueños.

11 Dower, 1. 
song, early music history on the island, and perspectives from musicians on musical life in Puerto Rico.

Edgardo Diaz Diaz’s “Puerto Rican Affirmation and Nationalism: the cases of Campos Parsi and Aponte Ledée” (1996), explores cultural and musical nationalism with respect to these two composers. He discusses attributes of Puerto Rican identity, politics, the convergence of multiple cultures, and the reasons why one composer chose nationalism while the other chose the avant-garde. This article marks ten years after Sonetos Sagrados, and is an essential contribution to the literature of his life because it discusses the divide between the perspectives of two these contrasting composers. The article offers personal anecdotes that clarify Campos Parsi's position on music, society, and politics. Previously reviewed literature on the topic of culture also discussed musical culture, politics, and Campos Parsi’s life.

Who or what were the primary and foremost social, cultural, and musical influences on Héctor Campos Parsi?

Puerto Rican musician, historian, and music critic, Gustavo Batista, interviewed the composer in 1984. This interview, available on Batista's website with interviews in Spanish of other prominent composers, offers a first-hand account of the influences of Campos Parsi's life, including his family, the musical environment during his childhood, turning points from exposure to specific music, and influential teachers and their thoughts on music. This interview was key in providing details of his life to examine his influences and discussions regarding his compositional process. ${ }^{12}$

In the interview with Gustavo Batista, Campos Parsi admitted to having had social advantages because he was part of a family that was educated during a time when education was

12. Batista, "Héctor Campos Parsi,” (1984). 
not compulsory nor equally and widely available to all children ${ }^{13}$. Children in Puerto Rico were going to schools as they were being built, and did not have equal access to education at the time of his youth. He also had an economic advantage because his father was affiliated with the bank of Puerto Rico. He owned a small farm that produced coffee and exported large quantities of oranges. Campos Parsi benefited from an early exposure to art music and musical activities. He came from a literate and musically educated family who had access to a piano as well as the island's most educated music teachers. ${ }^{14}$

There are two sources that are frequently cited due to their original interviews with the author. The most cited thesis on the life of the composer comes from Fernando H. Caso. In Héctor Campos Parsi in the History of Twentieth-Century Music of Puerto Rico, Caso describes the musical culture of the island with what he valued as significant contributions to musical life after 1898 just as Catherine Dower did in her book on music after war. He describes the composer's life through personal contact and identifies specific stylistic periods of his life until 1972. This thesis also includes articles that are not widely accessible, and contribute greatly to understanding the music history of Puerto Rico as does the work of Donald Thompson and Catherine Dower.

Moreover, José Montalvo's dissertation on Héctor Campos Parsi, his life and music: A biographical study with an analysis of four selected works, 1992, is one of the most significant sources chronicling the composer's life and the music history of Puerto Rico during his lifetime after the work of Fernando Caso which concluded in 1972. This comprehensive work also identifies Campos Parsi's teachers and helps to serve as a relevant source of cultural influence.

13. This was from the effects of the Great Depression.

14. Batista, 12. 
Montalvo also analyzes several selected works of the composer. These analyses do not include the vocal works analyzed in this paper.

This literature helps explain how culture affects musical influences and its consequences on Hèctor Campos Parsi's musical choices from his first vocal composition to one of his last contributions to art music of Puerto Rico. The combined content of literature supports the discussion on culture and influences. They provide a historic lens from which to view the structural and cultural components of culture. Cultural components discussed in the first chapter include political and social practices, as well as artistic institutions and contributions to their creative landscape. These sources also provide a foundation from which to view the influences of the composer such that his life experiences are tied to his environment which, in turn, affected his artistic expressions and advocacy for Puerto Rican art music. 
CHAPTER 1: THE CULTURAL ENVIRONMENT OF PUERTO RICO AFTER 1898: MUSIC, SOCIETY, AND POLITICS

The artist is born, not made, as is beyond discussion; however, he will develop and perfect his skills according to the environment in which he finds himself. ${ }^{15}$

The island lived under the rule of Spain for four hundred years. Relinquished and ceded to the United States during the Spanish-American War of 1898, the island found itself facing turmoil, economic upheaval, and social changes that would take years from which to recover. Yet the island's cultural life thrived during the rebuilding process and has found a new voice to express its folkloric elements in conjunction with the culture of its previous ruler, Spain. The island would seek a new identity in its redevelopment while the United States assumed control and restructured island life in all of its ethnic diversity and class issues.

Between a new imposed government, a government that did not speak Spanish, new laws to observe, the changing and devaluing of their currency, loss of property, and the most destructive hurricane in 1899 , the islanders suffered a devastating setback to their way of life and in the change of their national landscape as they knew it. Up until that time, the San Ciriaco hurricane was the worst hurricane that the island ever endured compared to those during 400 years of Spanish rule. Thousands of people lost their lives and homes, and suffered hunger as late as 1903. This was a major contribution to the feeling of cultural regression in Puerto Rico, and this sentiment would carry into several decades of the $20^{\text {th }}$ century. ${ }^{16}$

According to Catherine Dower, Theodore Roosevelt came to visit Puerto Rico around 1906, and he saw that the island was prospering in the fruit and sugar cane industries as well as

15. La Hija del Caribe (Trinidad Padilla de Sanz), “Notas Musicales," Puerto Rico Musical 1, no. 1 (February 15, 1906): 5-6, quoted in Donald Thompson, Music in Puerto Rico: A Reader's Anthology, “The Twentieth Century”, (Maryland: Scarecrow Press, Inc., 2002), 86.

16. Dower, 18-20. 
tobacco. As a result of this promising growth, Roosevelt asked Congress to grant them US citizenship. Under McKinley, the US had previously established and approved free commerce from the Foraker Act of 1900. The Jones-Shafroth Act of 1917 under Woodrow Wilson ${ }^{17}$, officially gave Puerto Ricans US citizenship while maintaining their citizenship as Puerto Rican citizens a year before the end of the first world war. Despite the establishment of a new Puerto Rican government with a governor and bicameral body, any action taken by Puerto Rico could be vetoed by the United States government. The first political parties formed around the principles of autonomy or independence. Political differences between Puerto Ricans continue to this day with respect to representation, welfare, and power over their own affairs. ${ }^{18}$

Industrialization efforts on behalf of the US created job growth and an increase in exports under Operation Bootstrap in the 1940s. This included a tax-shelter for US corporations that lasted into the late twentieth century. The island government, which was particularly interested in statehood-facilitated economic growth, placed the focus on global exports and less on local markets. The consequences of this effort led to American corporations setting up businesses on the island that gave them an unfair advantage over Puerto Rican merchants all while offering a pittance to the Puerto Rican worker. Puerto Rico's first governor, Jose Luis Alberto Muñoz Marín, and the Puerto Rican Democratic Party, helped to move the island way from an agrarian business model to a more modern and corporate business structure.

The political history of Puerto Rico was divided with islanders wanting to completely assimilate or seek autonomy. This occurred as various parties formed throughout the early part of Puerto Rico’s history, the most noted in the Puerto Rican Nationalist Party. Puerto Rico’s

17. Woodrow Wilson became ill in 1915. His wife helped him serve until 1921. 18. Dower, 36. 
nationalist movement has its roots in the work and perseverance of lawyer, nationalist, and social activist / party leader Pedro Albizu Campos ${ }^{19}{ }^{20}(1891-1965)$. His father was from the Basque region in Northcentral Spain, while his mother's parents were Puerto Rican and African.

Albizu Campos attended the University of Vermont on a scholarship where he studied chemistry and engineering. He served in World War I with the African-American unit; after his service, he continued his education at Harvard Law graduating in 1921. He was able to speak eight languages which caught the attention of the US government, but he decided to return to Puerto Rico. His experiences with racism soured his impression of the US and fueled his quest for Puerto Rican independence. As a result of his efforts at independence and at any cost, he was jailed repeatedly in the United States and in Puerto Rico, but his support from the Puerto Rican people was in the thousands. Artistic voices also responded to this message such as poet, Juan Antonio Corretjer (1908-1985), who was a respected voice of the nationalist movement. His literature was considered an exhortation in the name of independence, and it would affect artists and musicians for many years. ${ }^{21}$

The discussions in the 1930s from the intellectuals in Puerto Rico illuminated the poverty that led to a lack of equity in education and class division. This lack created a deeper chasm in which poorer musicians would be unable to receive advanced music education. Only those that could afford to leave the island with a little more assistance from private sponsors and some

19. Albizu Campos initially joined the Union party in 1923, but he left the party when it was no longer interested in pursuing independence.

20. Antonia Darder, "Pedro Albizu Campos". Encyclopaedia Britannica, 2019. https://www.britannica.com/biography/Pedro-Albizu-Campos.

21. Antonia Darder, 2019. 
government support could hope to pursue a life of music. The class division also elevated the music of the elites of society and subdued the music of the poorer, working class.

In musical life, the manner in which artists were supported by the Catholic Church ceased to exist after to the Spanish-American war. The Catholic Church had a close relationship with the government under Spanish rule. The United States separated the church from the state and the church was not funded. Many of their buildings were annexed by the US military and financial support for the citizens ran dry. Musicians lost access to perform via ensembles, including the church organists. ${ }^{22}$ The economic turmoil suffered by the islanders was also brought on by the reduction in value of their currency. Instead of silver, gold was the preferred money standard. They were unable to trade, and the tariffs imposed by the United States made it impossible for them to sustain themselves. Spain stopped buying their coffee and the United States would not consume it as it was too strong. Although they had some economic development as a result of tobacco, coffee and sugar, they suffered tremendously as a result of all of these changes to their economic and social lives. ${ }^{23}$

The government of Puerto Rico under Spanish rule was able to offer financial support and scholarships to musicians to study overseas. Unfortunately, the US support was heavily diminished and scholarships were terminated for those that were already studying abroad just before $1915 .{ }^{24}$ The US government in Puerto Rico would continue to assist students in the continuation of their studies while they installed an educational system on the island. As the US sought to model Puerto Rican schools in the image of US schools, the American government sent

22. Fernando Callejo Ferrer, "Música y músicos portorriqueños,," (1915) in Donald Thompson, Music in Puerto Rico, 88.

23. Dower, 18.

24. Ferrer in Thompson, 88. 
Puerto Rican teachers to the US for education training; This included basic music education.

However, the focus was on "practical life" and on a "lack of true love for the higher manifestations of the spirit. ${ }^{25} 26$

Although teachers were receiving training and some of the island's children were attending school, much of the island was illiterate. After 1900, the US government took measures to structure schools that functioned similarly to those in the US. Universities including the University of Puerto Rico, founded in $1903^{27}$, thrived and expanded throughout the island. Catholicism, which had been the main religion on the island under Spain, was supported by the appointment of a bishop and schools no longer were connected to the church. Life began to settle and improve for most of the islanders over time with the implementation of communication systems, electricity, infrastructure, and transportation. With the work of Governor Luis Muñoz Marin and Commissioner Mariano Villaronga Toro, the department of Public Instruction would pave the way for Spanish to be the primary language of instruction once again with English being offered to students as a subject in $1949 .{ }^{28}$

Puerto Ricans sought to establish music education on the island, but lack of support and political pushback prevented them from creating music schools until years later under new leadership. Governor Luis Muñoz Marín was responsible for Operation Serenity ${ }^{29}$ which paved

25 Aristides Chavier, "A Plea for Music in the Schools", (1936) in Thompson, 91. Chavier was a musicologist, pianist, and composer who was active in Puerto Rico during the 1930s known as the Generation of 1930, a time attributed to a rise in the expression of social issues in the arts. It was an intellectual movement that brought awareness to and criticism of the Great Depression's tragic effects on Puerto Rico.

26. Dower, 63.

27. The University of Puerto Rico began as the Insular Normal School in 1900.

28. Dower, 29, 34.

29. Enciclopedia de Puerto Rico, "Operation Serenity," https://enciclopediapr.org/en/encyclopedia/operation-serenity/ 
the way for the creation of The Conservatory of Music of Puerto Rico which was established by law in 1959. This conservatory was critical in the training of instrumentalists for the Puerto Rican Symphony Orchestra as well as the Casals Festival. ${ }^{30}$

Founded in 1956 by Pablo Casals, the international Pablo Casals Festival, which was also associated with the conservatory, was a destination for international performers during their summer concert series. While some celebrated this connection to the world, others such as composer Rafael Aponte-Ledée criticized the festival for excluding the music of Puerto Rico's composers in favor of the "other". ${ }^{31}$ This gave the outside world a false democratic impression of the island. Composer Francis Schwartz also noted the interesting connection between the festival and the old idea that concert music should represent the traditions of older European works. ${ }^{32}$ The underlying reason these concerts continued as they did was due to the enormous funding from the Ford Foundation and the image the government wished to present to the world. This division between musicians would prove problematic for many years due to its roots in old political wounds representing tensions among those seeking independence and those seeking statehood.

Festivals as well as cultural institutions are the stronghold of Puerto Rican culture and history, and its oldest helped preserve their culture during the transition of government. The Ateneo Puertorriqueño was a theater for the fine arts and sponsored contest that awarded prizes to composers, poets, and others in the arts. It was founded in 1878 and was not affected by the government transition of 1898 . Puerto Rico's first theaters in the early part of the $20^{\text {th }}$ century,

30. Conservatory of Music of Puerto Rico, "History," cmpr.edu/cmpr/historia/ 31. Rafael Aponte-Ledée, "Casals: un agente para la penetración cultural," in Thompson, 102-104.

32. Francis Schwartz, "Un festival que se llama Casals," in Thompson, 105. 
included the works of playwrights from the island thanks to the patronage of the Ateneo of Puerto Rico. The voices of "lo puertorriqueño [sic]" which were contained in theatrical works or areyto $^{33}$ were brought into the light after 1938 with the help of the Emilio Belaval (1903-1972). ${ }^{34}$ 35

Writers during the 1930s voiced their sociopolitical concerns through their works on the stage which still carried the echoes of Spanish theatre. The performances in these theatres included, operas, children's theatre, and productions that catered toward the needs or desires of the classes. Productions representing the Spanish days gone by were a favorite of the elites and intellectuals. Whereas educational theatre serving the working class depicted, for example, how to prevent their own "exploitation at sugar refineries". ${ }^{36}$

The Ateneo also provided a home to new music in the1960s with composers such as Rafael Aponte-Ledée and Francis Schwartz in a new group called Grupo Fluxus. This group featured performances of their works as well as works by contemporary composers of new music such as John Cage, Edgar Varèse, and Luciano Berio. ${ }^{37}$ This gave the Puerto Rican audiences an opportunity to become acquainted with the innovations in $20^{\text {th }}$ century music in contrast to the music being sponsored by the Pablo Casals Festival. It is at this point in time that Puerto Rican

33. The areito or areyto is attributed to the Taino's highest expression of artistic combinations.

34. According to the Cambridge History of Latin American Literature, Volume 2 edited by Echevarria and Pupo-Walker, the Amerindian term areyto is associated with national theatre (Areyto) and is attributed to the work of Emilio Belaval. p. 501-502

35. Dower, 78.

36. Gilda Orlandi as published in the Enciclopedia de Puerto Rico - September 8, 2010. enciclopediapr.org/en/encyclopedia/performing-arts-in-puerto-rico/

37 Francis Schwartz, “Grupo Fluxos de Puerto Rico”, 1990 in Donald Thompson's Music in Puerto Rico: A Reader's Anthology, 98-99. 
audiences have access to new music, older European musical styles, Nationalist music in art music and in popular song, as well as exposure to music from the radio and television.

Another institution established in 1955 known as the Puerto Rico General Archive also called the Archivo General de Puerto Rico, was created to be a primary source of musical documents and musical collections from the time of Spanish rule through the 1898 and the US takeover according to Donald Thompson (1986) and was affiliated with the University of Puerto Rico for one year before its transfer to the Institute of Culture of Puerto Rico. The Institute of Culture of Puerto Rico (Instituto de Cultura Puertorriqueña also knows as the ICP) houses and preserves the culture of Puerto Rico, which includes musical recordings, videos, and archived periodicals.

Aside from institutions, old performing ensembles such as the Insular Police Band brought relief to the island along with the US military band. They provided music for the dignitaries as they took their new posts on the island. During these celebrations, the Puerto Rican danza continued to sound during the change of political structure. ${ }^{38}$ Around 1907, as Puerto Rico was developing, performances for government dignitaries, musicians continued to program and perform music by Puerto Rican composers as well as music by Haydn, Mozart, and Beethoven. These included works such as the island's own danza, "La Borinqueña", which was performed by island musicians. 394041

38. Dower, 30-33

39. Portal del Gobierno de Puerto Rico, "Himnos Oficiales," https://www2.pr.gov/SobrePuertoRico/Pages/Himnos-Nacionales.aspx

40. The tune was played in the form of the danza. The original composer was Felix Astol Artes (1867); it became the national anthem in 1952. The text was officially added in 1977.

41. Dower 48-49. 
The Puerto Rican danza, Puerto Rico's musical genre born out of the combination of the Cuban habanera and the Spanish contradanza, was attributed to the composer Manuel Gregorio Tavárez and later, Morel Campos. Composers such as Héctor Campos Parsi composed in or alluded to this style in their works as it was a standard form of Puerto Rican musical expression on the island from the late $19^{\text {th }}$ century into the early part of the $20^{\text {th }}$ century. This musical style was and is significant because it was born on the island before the United States takeover. The danza would transform over time from instrumental dance music, to popular song, and ultimately, a nostalgic and folkloric song existing in both contemporary and art music circles. ${ }^{42}$

According to Puerto Rican composer and contemporary Amaury Veray, the danza was the musical symbol of Puerto Rican culture. Unlike other musical innovations, it escaped obscurity through transcription. The dance genre was attributed to the culture of the city of Ponce although it was originally attributed to the San Juan composer, Manuel Gregorio Tavárez. After years of cultivation, Juan Morel Campos began in this style and molded it to capture the essence of all that was Ponce. The insular atmosphere of Ponce protected the musical form from outside influences; thus, it is considered an unblemished hallmark of the "highest goal of Puerto Rican art music."43

Historically, there are three different periods of the danza which correlate with the political climate of Puerto Rico. The political categories by time or period capture the inception of political ideologies, the process of opposition between integration and independence, and their ramifications. These three periods are paired with the composers who Jose Ignacio Quintón. This

42. Dower, 5-6.

43. Amaury Veray, "La mission social de la danza de Juan Morel Campos," in Donald Thompson, Music in Puerto Rico: A Reader's Anthology, (2002), 65-66. 
"intimate dance" for couples was enjoyed by the "emergent middle class" and those with means. ${ }^{44}$

Future discussions in opposition reflect unharmonious sociopolitical views with the national anthem, which is now a sung danza. Angel G. Quintero Rivera argues that the danza could easily have been a seis (to be discussed further in this chapter) instead of the danza because it also combines elements of the island's three prevailing ethnicities: Spanish, African, and Taino. The author also says the danza was a form created by artisans (working class) for the hacendados (employers) and the reluctance to accept the danza as a symbol of Puerto Rican culture is because of this perspective. He also suggested that prevailing political hierarchy in Ponce unilaterally decided on the danza because it purposefully excluded most of the attributes of African rhythms. ${ }^{45}$ This is the main reason why, in retrospect, many citizens find the association and the history of the danza worrisome and less representative. Donald Thompson concluded that he believes that one should not analyze "cultural phenomena as "representing" specific social classes", but rather we should examine the relationships between all aspects of the people within these groups or the "dynamic of [these] relationships." 46

Unlike the danza, art songs were grounded in the style of European expression. The earliest art songs were attributed to Jose Ignacio Quintón. His first art songs titled "Dudas" (doubts) and "Tristeza" (sadness) were labeled as Lieder, but are the only songs that exist in his collected works. ${ }^{47}$ Early $20^{\text {th }}$ century songs that were considered art songs were danzas with text

44. Veray in Thompson, 67.

45. Angel G. Quintero Rivera, "The Danza: A Sociopolitical View”, in Donald Thompson, Music in Puerto Rico, 71-79.

46. Donald Thompson, "Methodological Epilogue," Music in Puerto Rico: A Readers' Anthology, 80-81.

47 No dates are available for these compositions. Although they are inaccessible at this time, they are listed in his complete works in Caso's thesis (Caso, 7). 
added to them. Popular songs, such as those by Rafael Hernandez Marín exemplify a tight combination of art and popular music.

Hernández's songs capture the heart of the Puerto Rican people's deepest desires, pains, patriotism, and concerns. In Margot Arce's 1939 article, The Songs of Rafael Hernández, she warns that the people of Puerto Rico may be committing "cultural suicide" by overlooking the culture of Puerto Rico while embracing the high art of cultures from abroad. ${ }^{48}$ This sentiment is reflected in the socio-political turmoil of the times. Rafael Hernández's songs, still popular to this day, are performed with reverence by both commercial artists as well as classical singers.

Art songs of Puerto Rico were also affected by the political upheaval and shifting of loyalties on the island as well as the Puerto Rican identity within Puerto Rico's culture. The denial of nationalism was politically motivated pitting statehood against independence.

Composers chose to side with either autonomy or independence as anyone would politically, but some did not believe it was completely necessary. Political choices affected composers' musical styles such as either nationalism or avant-garde. Campos Parsi fell into the line of nationalist composers because he would not completely embrace $20^{\text {th }}$ century techniques for many years. Composers such as his contemporary, Aponte Ledée composed using modern techniques much earlier in their output and their music had less obvious folklorist material.

Pianist and organist Julio Carlos de Arteaga's 1893 article on A Professional Musician's View $^{49}$, discusses the song style in Puerto Rico as being influenced by both Spain as well as the Puerto Rican jíbaro. "The essentially Puerto Rican folk songs are based on modern European harmony... derived from characteristics... from peninsular Spain." ${ }^{50}$ He believed that there

48. Arce in Thompson, 109.

49. Arteaga in Thompson, 24-26.

50. Arteaga, 24. 
existed a special kind of counterpoint particular to Puerto Rican popular music from his 1893 perspective, which was a dialogue between the singer's couplets and the jibaro's improvisations on the cuatro. ${ }^{51}$ With respect to melody, Arteaga said that, "Puerto Rican folk song is often laid out like the old plainchant, that is, within the melodic compass of a fifth (tonic to dominant), with an occasional use of the lower leading tone and frequent employment of the sixth scale degree. ${ }^{52}$

In the interview with Batista, Campos Parsi mentioned that one of his fondest musical memories is of the seis $^{53}$ which is considered the musical symbol of the jíbaro. Arteaga notes that there are three aspects of the seis of note: "(1) the constant use of duple meter; (2) the frequent use of triplets... and (3) final cadences which frequently end on the dominant in root position or in second inversion, with the supertonic in the bass. According to Arteaga, the meter may also have "alternating duple and triple meter." ${ }^{54}$ Additionally, he stated the Puerto Rican style lent itself to ornamentation and improvisation. Arteaga believed that these two elements were representative of the way in which the Puerto Rican jíbaro would play the cuatro. Other instruments played with the stringed cuatro include the güiro, a scraped wooden instrument left over from the Tainos.

Other forms of musical expression on the island incorporate the sounds of Africa in the bomba and plena. These heavily percussive forms were connected with dances and not considered contributions to art music. Some dance musical styles were an issue of contention as

51. Thompson, 24-25

52. Arteaga, 25

53. Campos Parsi, Entrevista, 3

54. Arteaga, 25. 
some Puerto Ricans believed that it represented the sound of Puerto Rico. Those that opposed it may have had concerns that had more to do with racial biases.

Puerto Rican folk music or folkloric musical genres besides the aforementioned include the decima, Christmas aguinaldos ${ }^{55}$ and villancicos, as well as European leftovers such as the mazurka, waltz, and polka. Puerto Rico comes alive with music of the parranderos $^{56}$ during the holiday season with musicians serenading prospective neighbors with aguinaldos which were Christmas songs that transformed into non-religious thematic songs. These songs were spontaneous and depicted everyday life. The aguinaldos and their relative, villancicos, were musical influences from Spain. Similarly, the decima, which is the foundation of the seis, involves the use of a ten-line, eight-syllable poem with specifically ordered rhymes in the form ABBAACCDDC and also is of Spanish influence. ${ }^{57} 58$

The Spanish also brought zarzuelas to the island that were well-received and loved by the Puerto Ricans. Opera was an imported genre, but Felipe Guitiérrez y Espinosa (1825-1899) composed the first known Puerto Rican opera in 1855 titled Guarionex, named after a Taino chief. Years later, Puerto Rico started to compose its own operas with several operas getting the attention of people on the island in the 1980s. The slower growth of opera as a genre may have been due to a delay by popular songs and the development of the radio and television. ${ }^{59}$

The identity of Puerto Rico continues to be part of the discussion on the island through multiple disciplines. In Puerto Rican Affirmation and Denial of Musical Nationalism: The Cases

55. Aguinaldos are synonymous with carols.

56 Parranderos were musicians that serenaded the neighborhood during the holidays. 57. The decima was frequently improvised and the form is learned via oral transmission. 58. Gary Morales, "History of Puerto Rican Music." Enciclopedia de Puerto Rico. September 4 2014. https://enciclopediapr.org/en/encyclopedia/history-of-puerto-rican-music/. 59. Morales, "History of Puerto Rican Music." 
of Campos Parsi and Aponte Ledée, Edgardo Díaz Díaz [sic] explores the conversation regarding the definition of the Puerto Rican as the self versus the other. This subject permeated the minds of Puerto Ricans as they pondered how to define the representative or folkloric characteristics of their culture. The question asked is about what were internal or external characteristics that made up their identity. This is a direct consequence of the Puerto Rican intellectual community that thrived in the 1930s. ${ }^{60}$

The composers were interviewed separately in Diaz's article where they discuss what identity is in new music as well as in traditional or nationalist music. Around 1950, composers such as Campos Parsi and his contemporary, composer Amaury Veray, worked to create the Manifesto de Acción Musicale. This manifesto announced their dedication to the promotion of Puerto Rico's music. Their goal was to seek collective action in order to elevate the art music of Puerto Rico to the national stage, and to bridge the gap between, for example, the danza and other popular forms of expression. They wished for it to be received as serious art music and representative of the island. Those composers opposing this view were not excluded from political reactions, instead they defined a new path toward musical expression as whole. The expressions in the titles of their works and in the text of their songs would hold their Puerto Rican identity. ${ }^{61}$

Composers, such as Aponte-Ledèe, reacted to what seemed like cultural imperialism because the optics concerning the formation, funding, and musical programming at the conservatory reinforced the agenda of Western art music. To composers of new music,

60. Edgardo Díaz Díaz, "Puerto Rican Affirmation and Denial of Musical Nationalism: The Cases of Campos Parsi and Aponte Ledée." (Latin American Musical Review / Revista De Música Latinoamericana 17, no. 1, 1996): 1-2.

61. Diaz, "Puerto Rican Affirmation and Denial of Musical Nationalism: The Cases of Campos Parsi and Aponte Ledée", 2. 
the strong, hegemonic arm of the United States attempted to permeate the conservatory via funding while the institution appeared to symbolize that which was only Puerto Rican. Ironically, the situation involving Puerto Ricans who sought to define Puerto Rican identity was fraught with dissonant discussions.

After 1898, Puerto Ricans experienced a process of continuous and transformative cultural processes from the merging of Taino Indian (cultural transplantation of Spanish over Taino) and Spanish cultures as well as African culture via acculturation as a result of the US takeover. Consequently, when examining Puerto Rican musical identity, it is necessary to include the historical convergence of these cultures. The complexity of Puerto Rico's sound negates a homogeneous perspective of their music as their identity is a mix of non-linear heritage. The value or relevance of their identity is not in question, but it is difficult to dissect and trace exactly where specific genres originated. This could be due to the imposition of other cultures from the US and Spain as well as the culture of the African slaves who were freed by the Spanish. ${ }^{62}$

In conclusion, the cultural diffusion of Spain into Puerto Rico was represented by the acceptance over time of religion, music, and language. Very little of the Taino remained by the time the United States came in 1898. While the United States government made changes to the island, the islanders held on to their own practices in music by continuing to perform the music of Europe and Puerto Rico, the latter example is the Puerto Rican danza. Ironically, the danza itself, although attributed to Puerto Rico, is a fusion of Cuban and Spanish musical styles, but is inherently Puerto Rican. This is important to understand because it sets the context for the following chapter. With a ratified constitution in 1952, the Puerto Rican people felt a sort of

62 Spain abolished slavery in Puerto Rico in 1873. 
independence and renewed their focus on their folkloric customs. The components of culture such as social and political organization and government structures were firm and seemingly autonomous with more mainland representation over time. The customs and traditions of the citizens remained connected to prior celebrations and observances such as those affiliated with the Christian religion. Their economy and language were dominated by the United States, but Puerto Ricans maintained their Spanish language and cultural identity. 
CHAPTER 2: HECTOR CAMPOS PARSI'S MUSICAL LIFE - EDUCATION, INFLUENCE, AND CONTRIBUTIONS

On October 1, 1922, Elisa Parsi Bernard and Jose Miguel Campos Fernando welcomed a son and soon-to-be composer, Héctor Miguel Campos Parsi. He was born in Ponce, a city that was considered one of the most culturally prominent cities of Puerto Rico, to a musical and educated family of means. From birth, Campos Parsi had the advantage of being part of an elite social class because of their income, education, and circle of influential friends. In a future interview with Gustavo Batista, he acknowledged that this advantage was unique. The cultural environment in Puerto Rico and in his home during his early years would affect him as a composer and shape his thinking throughout his life.

In his 1984 interview with Gustavo Batista, Campos Parsi said that his musical interest may have been ambiental or from the environment. Meaning that he could have been heavily influenced by something environmental either familial or from society. His parents, close family members, and friends of the family made music in the home. Although he did not articulate it, his family and environment enculturated him, and instilled in him the essence of their culture. The generation before him were children during the Spanish-American war. As such, the island was in the process of acculturation due to its association with the United States and continued to digest the convergence of elements from Puerto Rican and Spanish transculturation. ${ }^{63}$

Music in the home was a way of life for Campos Parsi, and his parents were not the only musicians. His aunt, Teresa Carreño, was a first-rate pianist in his opinion, and he mentioned that his grandfather played the flute. He claimed that the only way he could be lulled to sleep was to

63. Campos Parsi, 2. 
hear the danza, "La Borinqueña", as it was the first music he remembered hearing, particularly on the piano. His father Jose Miguel Campos Fajardo was a pianist, and he frequently played Beethoven piano sonatas when they lived in Utuado which would have been when he was two years old until the age of ten. Campos Parsi remembered how his father would play piano after the family meal, and how he heard and saw his family play his favorite danza at celebrations as well as his other favorite, the "Seis Chorreao." 64 The family also played music on the phonograph, and he found himself a fan of Beethoven and other European composers. ${ }^{65}$

Members of his family played instruments such as flute, violin, and had a great love of art music. His family was also in a higher class consisting of businessmen, military members, and his father was affiliated with the bank of Ponce. Being in this social class afforded them a piano, phonograph, access to concerts, as well as an influential circle of friends. It also helped that his family was one of the few remaining farmers who grew coffee and oranges on the largest farm they were allowed to own by US law. ${ }^{66}$

Campos Parsi was active as a child musician. He sang from a young age and participated in neighborhood concerts with his musically educated neighbors. As a child, he sang in local towns, and he became known as a "little tenor" in the region. His memory of these specific events may have contributed to his understanding of the singer's voice, and why his compositions are written well for the voice. His recollection of childhood events led Campos

64. The seis is a genre of dance music of the rural people of Puerto Rico known as jíbaros.) "Enciclopedia de Puerto Rico". https://enciclopediapr.org/en/encyclopedia/the-seismusical-expression/ Accessed September 5, 2019

65. The danza is Puerto Rico's most representative compositional genre of art music originating in the 1840s. Composers associated with this form are Manuel Gregorio Tavárez (1843-1883), Juan Morel Campos (1857-1896) and José Ignacio Quintón, respectively associated with the formative, mature, and later periods of Puerto Rican music history.

66. Campos Parsi, Entrevista, 1-6. 
Parsi to say that children need family in order to develop. He acknowledged how his family celebrated all of his accomplishments as a child, and this source of constant encouragement was a positive effect on his life. ${ }^{67}$

Campos Parsi stated that his influence may have resulted from various streams of influence such as listening to and watching his father play Beethoven sonatas on the piano, the environment, the constant celebrations in his home, and later, taking piano lessons when he was four years old learning to play the music of Handel and Mozart. During a gathering of family and friends, he was exposed to Bartók's Contrasts ${ }^{68}$ on the phonograph; it was a revelacion or revelation to him. His music education was serendipitously provided by people in his community that were prominent musicians or offspring of significant contributors to Puerto Rican musical culture. He lived across the street from Cecilia Muñoz de Negron who was the daughter of Jesus Maria Muñoz who came from a family of prominent Puerto Rican musicians. She became his music teacher when he was four years of age. Doña Cecilia exposed him to the music of Bach, Handel, and Mozart. It is at this time that he would put on shows with her children for their town and for others. ${ }^{69} 70$

Although his family moved to different towns, others encouraged him to continue private lessons. At 13, he received a scholarship from Margarita van Rhyne who praised his improvisations, and aimed to discipline his approach via piano lessons. She was the first person to see his potential for composition and not just a improviser that played by ear. However, this was also the first time that he realized he had a talent for improvisation. This talent was

67. Campos Parsi, 6-7.

68. Specifically, Béla Bartók's Contrasts Sz.111, BB 116 for violin, clarinet, and piano 69. Bartók’s influences included Olivier Messiaen, Alberto Ginastera, Aaron Copland and George Crumb.

70. Campos Parsi, 5-9. 
strengthened by arranging the music for church in the style of Bach - music he had only heard and never formally studied. Campos Parsi stated that he would hear melodies and come home to play them by ear. He credits his family for nurturing and praising his attempts to play by ear music he had recently heard. This habit followed him for years, but later, it helped him gain admission into the New England Conservatory. Van Rhyne had a large art music library of literature from all over the world. This was a large part of his education before he started at the university. As research suggests, the mind of a child absorbs harmonic structures in early childhood, even before the child can process the information in higher ordered thinking. It is apparent that these experiences were waiting until he developed tools of expression to manifest themselves. Until then, he would attempt his own compositions beginning with his first public performance of his own music. ${ }^{71}$

In 1941, he played his first composition in Santurce, a waltz titled "Rosa María", on the radio. Throughout the years, he composed more waltzes in honor and love for his mother. This was during his time at the University of Puerto Rico where he majored in biology, with a minor in psychology from 1939-1944. He stayed active in school organizations such as ROTC, an American military program, and theatre. These may seem like contrasting organizations, but his membership in the ROTC gave him the foundation of leadership as students of this program study leadership skills and learn to espouse the core values of officer training which include integrity, perseverance, and organizational skills. This kind of leadership training plus exposure to creative expression in the theatre was the seed starter for his directorship of the Institute of Puerto Rican Culture (ICP).

71. Campos Parsi, Entrevista, 3-11. 
In 1945 , he went to Mexico to study medicine at the National University of Mexico. ${ }^{72}$ While he was in school, Campos Parsi composed more waltzes. Although, he admitted that his father or others would have to transcribe music for him because he could not do it at this time. He had not yet received training in music theory. In Mexico, he met and heard the music of Carlos Chavez, who told him that he believed he would definitely end up studying music. Chavez must have seen his desire and ability as something to be nurtured. Unfortunately, Campos Parsi could not see how he could live as a professional musician. His family had appreciated music as entertainment. He never thought he would be a professional musician because of what his family thought. They believed that musicians were not considered "alta en la escala social" or high on the social ladder. ${ }^{73}$ He considered his family upper-middle class and, to him, being a professional musician was not a financially sound career. He attended medical school for a short while until he left school due to illness ${ }^{74}$. He returned to Puerto Rico for a short while until he received an opportunity that would set in motion his life a professional composer.

While the world was recovering from World War II, Campos Parsi waited for a year to gain admission to a university in the US. In the meantime, his family had him working for the family insurance business in Ponce for which he received training in Baltimore where he graduated from an insurance program in 1946. Upon his return to Puerto Rico, his music career was still on hold due to his need for income. He worked as a salesman of chocolate and insurance policies. After his cousin, a pianist, gave up a scholarship ${ }^{75}$ from a music educator and

72. Darder, 2019.

73. Campos Parsi, Entrevista, 11

74. Serafín Méndez-Méndez and Ronald Fernandez, Puerto Rico Past and Present: an encyclopedia, (California: Greenwood, an imprint of ABC-CLIO, LLC) 2017.

http://www.credoreference.com/book/greenwoodqji. 72.

75. Campos Parsi, 14. 
well-known sponsor in Puerto Rico, he received that scholarship instead to study at the New England Conservatory.

Campos Parsi was admitted after a successful audition despite lacking any knowledge of formal training. His years improvising at the keyboard caught the attention of admissions. He was assigned to study theory under Harold Schwab for six months before formal acceptance in 1947, which was before studying under Francis Judd Cooke. This is also the same year in which he composed the third song, "El Arroyo" from Canciones de Cielo y Agua.

He devoted several years to correcting his deficiencies in music theory both in the US and in France. Campos Parsi, in his interview with Batista noted how he appreciated Ivan Waldbauer's ${ }^{76}$ high standard for ear training and solfege because it allowed him to see how deficient he was in it. He knew this was an impediment to his ability to succeed as a composition major at the conservatory. He was very active as a student as a composer, recitalist, and participated in musical organizations and clubs. Cooke who had studied with Donald Tovey, ${ }^{77}$ believed in Campos Parsi's promising abilities and encouraged him to go to Tanglewood where he studied with Aaron Copland in the summer of 1949. Campos Parsi was given work that allowed him to attend lectures by Copland which provided enrichment because he was so deficient in composition. ${ }^{78}$

Being at Tanglewood must have been an eventful time for Campos Parsi. He was surrounded by an establishment at the Berkshires that was a relatively new institution. The summer festival brought together aspiring instrumentalists, singers, and composers including

76. Ivan Waldbauer (1923-2012) was a Hungarian pianist and music historian that helped archive the works of Bartók.

77. Donald Tovey (1875-1940) was a British pianist, musicologist, and theorist.

78. Campos, Parsi, 17-19 
established composers. These composition instructors were Olivier Messiaen (1908-1992) whose assistant was Irving Fine (1914-1962), Leonard Bernstein (1818-1990) who was the orchestral assistant to Serge Koussevitzky (1874-1951), and Aaron Copland (1900-1990). After a very brief period studying with Paul Hindemith (1895-1963) ${ }^{79}$ at Yale in 1950, Campos Parsi was invited to study composition and counterpoint with Nadia Boulanger (1887-1979) in France where he had the opportunity to take a year to study ear training and harmony with Annette Dieudonné (1896-1991), assistant to Boulanger. This opportunity was afforded to him by the help of Copland who contacted Mariano Villaronga Toro. Toro was a Puerto Rican Harvard graduate, educator and commissioner of Public Instruction of Puerto Rico that secured a grant for Campos Parsi. Upon the composer's return, he was required to work at the Department of Instruction. ${ }^{80}$

Nadia Boulanger was serving as the director of The French Music School for Americans at Fontainebleau. Boulanger's style encouraged composers to bring out who they were so their compositions were representative of what they valued in a culture, particularly their own. This style directly affected Campos Parsi and is evident in his choice to compose in a nationalist style.

Campos Parsi was attentive to his studies, but he set aside his own musical impulses so he could learn how to communicate in a neoclassical style. He put aside his thoughts on using timbre as form because he knew he could not explore that with Boulanger the way that others were experimenting with electronic music. Instead, he dedicated himself to studying counterpoint, orchestration, and composition with Boulanger. He said his neoclassical period started when he studied under Cooke as he was receiving training for the first time around 1947.

79. Campos Parsi, in his interview with Batista, said that he does not include his studies with Hindemith because it was only for a few months before going to France to study with Boulanger.

80. Serafin Méndez-Méndez and Ronald Fernandez, 72-73. 
Then, his intuitive period was studying under Boulanger while he was developing his compositional technique around 1951. During this time, he completed his song cycle, Canciones de Cielo y Agua. ${ }^{81} 82$

Financial difficulties forced him to return to the island in 1953. Upon Campos Parsi's return to Puerto Rico, he pursued his desire to promote the music of Puerto Rico. Fulfilling the requirement of the grant he received, he worked for the Free Schools of Music (Escuelas Libres de Musica) as an evaluator. He developed the solfege and theory program in Puerto Rico similar to his previous training in New England using the theory literature given to him by Paul Hindemith. After receiving a solid foundation for music composition, and after participating in large cultural events outside of the island, he was ready and qualified to take on educational and leadership roles.

Pro Arte Musical de Puerto Rico was founded by Puerto Ricans in 1932 to provide space for creativity, encourage artistic collaboration, and to promote the music of Puerto Rico. Over the years, this institution focused their attention outside of Puerto Rico. This caused island artists and intellectuals to create a call to action. In 1950, this group, which included Héctor Campos Parsi and Amaury Veray, founded Acción Musical ${ }^{83}$ in conjunction with the Ateneo Puertorriqueño. Similar to Pro Arte, they used new resources such as radio, news outlets, and venues to promote Puerto Rican music. ${ }^{84}$

Campos Parsi contributed to the musical culture of Puerto Rico with his return. He formed the Inter-American Festival of the Arts as well as the San Juan Chamber Music Festival.

\footnotetext{
${ }^{81}$ Campos Parsi, 17-21.

${ }^{82}$ Caso, $97-98$.

${ }^{83} \mathrm{He}$ signed this manifest when he returned to Puerto Rico in 1953.

${ }^{84}$ Caso, $10-24$
} 
He became the professor of composition and theory at Conservatorio de Musica de Puerto Rico in San Juan, Puerto Rico. Throughout his life, Campos Parsi won numerous awards for composition including the Maurice Ravel Prize in Paris, $1953^{85}$. His compositional style embraced neo-classicism in the mid-1950s, musical nationalism, later aleatory and electronic music. He was also known for being a music critic, and he wrote poetry as evidenced by the text he provided for his own composition, Canciones de Cielo y Agua. He was pouring his artistry into the island as the island itself was blossoming with its own social, political, and cultural growth.

During his employment at the Conservatory of Music in Puerto Rico in the 1960s, things were not going very well for him. He stated that the conservatory had "fallen into conservative hands [and] it was a sick Institution[sic] [that] did not respond to [his] manner [nor did it] respond to the actual necessities of the island." 86 This sentiment coincides with the events following the installation of the Pablo Casals Festival, plus the conservatory's American funding which promoted music of the "other". This conflict led to his resignation from his job at the conservatory, and he returned to the ICP until 1981. He remained active as a cultural administration manager promoting and cultivating the artistic culture of the island.

Campos Parsi continued promoting cultural life on the island when he was asked to write music for film. During DIVEDCO’s filming of Puerto Rican life, composer Jack Delano (1914-

85. Serafin Méndez-Méndez and Ronald Fernandez, 72.

86. “...había caído en manos conservadoras...era un Institución enferma... no responde a mi manera... no responde a las necesidades actuals del país (Campos Parsi, 29-30)." As stated in his interview with Batista. He also suggests that issue was prevalent during the time of the interview. This means that, in his view, the school had this problem from the 1960s until the year of the interview in 1984. 
1997) ${ }^{87}$ involved Campos Parsi in composing music for several movies. One of his most noted is the music to the film, Modesta (1946), which represents his nationalistic writing in 1951 and for almost a decade after that. In addition to music for film, he composed for the ballet. He noted that his ballet Juan Bobo was one of his most important works for orchestra such that it revives the musical genres from the island in the early part of the $20^{\text {th }}$ century. These events are particularly critical because the majority of composers during this time are composed new music such as electronic music. Meanwhile, Campos Parsi continued to compose music that he believed represented Puerto Rico until 1959.

Campos Parsi found a new wave of influence in the music of composers such as John Cage and Pierre Boulez. Although this marks a period in his life where he experimented with electronic music, it is not because it is a completely new concept to him. He had worked with Henri Schaeffer in Club D'Essai ${ }^{88}$ in Paris for eight months where he was exposed to musique concrète and electronic music. He held firm to his commitment to the neoclassical style as he studied with Nadia Boulanger. The desire to work with newer styles of composition would remain with him until he felt the need to embrace modern techniques in the years around 1960. He composed very little modern, experimental music as he felt that he was already committed to his writing style as a neoclassic composer. As popular music became the norm and his nationalist style of writing was less popular, his output came to a halt for a period of around three years between 1961 and 1964. Although he had continued some of his writing projects, his attention

87. Jack Delano was a Ukrainian- born photographer who worked for the US Farm Security Administration. He came to Puerto Rico in 1946 and stayed until he died. He was a composer and music teacher as well. https://www.icp.org/browse/archive/constituents/jackdelano?all/all/all/all//0

88. Club D'Essai was known in Paris for creating electronic sounds and using recording equipment to distort sounds which they would use in their compositions. 
turned inward as he pondered if his music was relevant anymore (Parsi, 35). However, he was asked to compose a work in 1965 which he chose to represent in a manner consistent with his style before his experimental period. It was a tonal, orchestral work titled, Duo Trágico in Memoriam John F. Kennedy ${ }^{89}$. This period marks a comeback for Campos Parsi where he composes his most mature, prolific works. ${ }^{90} 91$

By 1966, the composer's voice was free of the folkloristic elements that permeated his previous compositions. In his interview with Batista ${ }^{92}$, the composer does not believe that he would have considered himself a composer after 1966. He began compositions that he would throw away or never finish including an opera. Around 1972, he began his research for La Gran Enciclopedia de Puerto Rico, Vol. 7: Musica, which he completed and published in 1976. During the next decade, he was able to express himself in his mature and informed writing style while reviving the old Spanish influence inherent in the sacred Spanish text of Sonetos Sagrados published in 1986.

Campos Parsi served as a faculty member at the University of Puerto Rico until he died in 1998. He leaves behind literary contributions from his days as a music critic with Puerto Rico’s most notable news organizations and periodicals as well over a dozen compositions for voice. His output includes orchestral music for the stage, ballet, and film as well choral and piano works $^{93}$.

89. Serafin Méndez-Méndez and Ronald Fernandez, 73.

90. Caso, 98-101

91. Campos Parsi, 33.

92. Batista, 36-37.

93. Serafin Méndez-Méndez and Ronald Fernandez, 72-73. 


\section{CHAPTER 3: SONG ANALYSIS AND TRANSLATIONS}

I see myself as a big ingestor [sic] of things who in turn digests them, transforms them and returns them (Hèctor Campos Parsi). ${ }^{94}$

\section{Canciones de Cielo y Agua}

This song cycle was published in Paris in 1953, but the cycle was written out of order with the third song, "El Arroyo", for soprano and harp written first in 1947 which was dedicated to Elizavetha [sic] Sokoloff. The first two songs were dedicated to Flore Wend and were published together with the third song in Paris, when he was studying composition with Nadia Boulanger in 1953. Campos Parsi sent an autographed copy to Spanish soprano, Maria Conchita Badia, but there are no records of her performance of them. This score is currently available under reserves at the Biblioteca de Catalunya in Barcelona, Spain while another edition is located at the Institute of Culture of Puerto Rico. He described this work as a "cascade of rippling arpeggios." 96 The first two songs of his song cycle, Canciones de Cielo y Agua, although published for piano and voice, could be arranged for harp. Since the third song was intended for harp, I contend that the first two songs could also be accompanied by harp. It is interesting to observe that the music of Spain often featured the harp. This is his earliest song cycle and is a representative of his earliest thoughts from years of influence up until that point in his education.

94 Hèctor Campos Parsi as quoted in Caso, 62.

95. Note on all songs: The vocal line of each song from both works ends on an interval of a second between the last two pitches. In Canciones de Cielo y Agua, the last interval is always a M2.

96. Jose Montalvo, Héctor Campos Parsi His Life and Music: A Biographical Study with an Analysis of Four Selected Works. PhD diss. New York: New York School of Education, Health, Nursing and Arts Professions, (1992), 68. 
I. "Los Signos en el Cielo..." (The Symbols in the Sky)

The opening of "Los Signos en el Cielo", indicates a rolled chord in Gm, however, the recitative-like vocal line outlines the G Hypophrygian scale, while the bass line outlines Phrygian on G. Campos Parsi. Phrygian was often found in Spanish flamenco music. At this point, he was new to training under Irving Fine, as noted in Caso's thesis, who said that these were "attempts at art songs" and "should not be judged too harshly."

Campos Parsi incorporated word painting in bass line on the words "sobre el sol", which translates to "over the sun". In this case, it suggests going over sol, as in the solfege syllables, sol-la, or the sixth scale degree from G: em6/5. Additionally, there is evidence of word painting in the vocal leap up the octave in the words, "las nubes" and "la luz." The text, "las luz se esconde", painted by the accompaniment as it seemingly hides a flash of an A-natural, perhaps a foretelling of its arrival at the conclusion of the song. The vocal line is responding to the action implied by the text, which has the affect of word painting as previously described.

Along with a trilled Spanish vocal opening on “Ay!”, the piano's rolled chord in m. 1 may indicate Campos Parsi's desire to use a harp in lieu of a piano, or it may show the influence of a strumming technique (rasgueado) (Torres, 2015) used in Spanish classical guitar or flamenco. In m. 3, the F\# is consistent with a raised third scale degree in Phrygian as it sometimes appears in flamenco. Another Spanish marker is on the Andalusian or flamencoinspired repetition of "doloridos" in m. 24 on the pitches G-Ab-Bb. Rhythmically, the triplets are reminiscent of the triplets that were prominent features of the Puerto Rican danza. ${ }^{98}$

97. Caso, 72.

98. The danza is explained later in the analysis. 
Finally, it may be concluded that Campos Parsi's exposure to Spanish art song in his early years, at home and in his environment, can be found in his music. Elements such as the rhythms of the Puerto Rican danza, the Spanish flamenco influence, and word painting similar to those found in villancicos are evident in this first song.

\section{II.” El Aguacero" (The Downpour)}

A troubled soul stirs in "El Aguacero", where a heavy rain carried away a sweetheart, and is sung in a scalar and simple melody similar to a modified decima. The song begins and ends in $\mathrm{d}$ minor. Overall, the tonality is consistent and rarely includes any other harmonies with the exception of g minor; there are a few chord changes or cadential points. Like the sound of a galloping horse, the bass line plays $\mathrm{C}$ and $\mathrm{D}$ repeatedly on an ostinato: $6 / 8 \mathrm{~d} \delta \delta$.

The song peaks when the voice expresses, "en mi alma atribulada" (in my troubled soul), with a fermata on the last syllable of "atribulada" on beat four. The accompaniment finishes a series of thirds in the tonic and holds onto a fermata on the last sixteenth note of the bar. A rolled gm7 chord creates a pause as the singer completes the phrase, "persiguiendo tu crucero!"99. The singer and piano accompaniment almost line up on a fermata on the first syllable of "crucero" on a Bb7 after which the Ab shifts to A to resolve to a d minor chord. The song concludes as it began, and the texture thins out as would the sound of rain as it stops, on D3 (right hand) and D2 (left hand).

This second song provides a contrast in tempo to the first and third songs because it is faster and more dance-like. The challenge for any singer will be the speed of the text. This song

99. The translation may hold multiple meanings, such as pursuing or chasing a water voyage. This interpretation connects the text to the next song like water running into a creek. 
is very difficult to perform at a fast rate and should be practiced for accuracy - preferably with a metronome. This song is set in a strophic form with a brief period of rest for the singer. The text is subservient to the rhythm throughout the song, which can pose another challenge to singers. Last, the rhythm influenced Latin dance rhythms. It would be helpful to keep that in mind while performing it.

\section{III. "El Arroyo" (The Creek or The Small River)}

"El Arroyo", which Campos Parsi composed first and dedicated to Elizavetha Sokoloff ${ }^{100}$, was described by the composer as falling arpeggios ${ }^{101}$ that appear similar to Ravel's second song, “Là-bas, vers l'église”, from Cinq Mélodies Populaires Grecques, 1904-1906. In Ravel's song, the piano accompaniment has the marking, sempre arpeggiando. Music of Spanish influence also featured arpeggiation in Spanish guitar or harp works.

The pitch content shows $\mathrm{B} b$ natural minor, which falls in line with the fact that his pieces tend to be modal via analysis. There is text painting in the accompaniment that appears after the words, "correr" (to run), in "juncos" in, and "juntos" (together). The latter expression, although similarly expressed, varies slightly as the sixteenths appear to flow out of a rolled chord similar to that found in Spanish music. These rolled chords create an ethereal and light texture that shapes the entire song. Campos Parsi may have intentionally set the text, "enredado", which means 'tangled', because the rolled letter " $r$ " in "enredado" makes it seem onomatopoeic. At the conclusion of the song, the right hand of the piano accompaniment echoes the singer's pitches on "tristes aguas, aguas tristes," and concludes on an isolated Bb.

100. Elizavetha Sokoloff's name appears with the letter V on the score. In other publications, such as Fernando Caso's thesis, it is listed as Elizabeth, (Caso, 72). ${ }^{101}$ Caso, 72. 
Although "El Arroyo" was Campos Parsi's first song, it fits well placed at the end of the cycle. It allows the imagery to flow from the first song seamlessly. This is because the text in the first song, "Los Signos en el Cielo", calls out to the signs in the sky with the first utterance on the word, "Ay." The text sets the stormy scene for the second song, "El Aguacero", where the downpour occurs with intensity expressed in a rapid tempo. The third song ties the work together because the singer, having lost their love in the previous song, can be heard crying over the "falling arpeggios". ${ }^{102}$ It is as if the singer's tears are the sad waters themselves.

Overall, these songs are examples of Campos Parsi's untrained composing style and show how well he was able to write for the voice. Because he grew up in a musical home, he was exposed to art songs from Europe, particularly from Spain. Presumably, his song forms would take a similar shape such as his third song is similar to Ravel's "Là-bas, vers l'église", which I mentioned earlier. Cultural elements that exist in this cycle mostly occur in the second movement with Latin American dance-rhythms. The imagery conveyed in these songs includes the term, "arroyos", which happens to be the name of a town that is far south of San Juan. Because these songs were composed before the majority of his musical training, they are raw examples of his talent at that time. They also are representations of what he may have thought art songs were supposed to be because of his exposure to Western art songs and art music, in general, as young child.

102. Caso, 72. 


\section{Sonetos Sagrados}

Sonetos Sagrados was written for soprano and wind quintet consisting of a flute, oboe, $\mathrm{Bb}$ clarinet, bassoon, and horn in F. It was published in 1986 when the composer was living in Puerto Rico, two years after his interview with Gustavo Batista, and was dedicated to Margarita Benitez. In the notes from the publisher of the only recording ${ }^{103}$ of Sonetos Sagrados, it is mentioned that the work is for soprano or tenor. ${ }^{104}$ The CD jacket of the recording with Bronx Arts Ensemble, 1989 (100 years from the US takeover of Puerto Rico), states that it was premiered in San Juan's Inter-American Arts Festival in 1986. This work is described by the author in Freeman's writing as "a small sacred cantata, each section casting a different light on the many faces of divine love." 105

Its purpose was to recognize the anniversary of Christopher Columbus's adventure to the New World. The music acknowledges five hundred years from the arrival of the Spanish, and it offered Spanish details within the body of the work. Some of these Spanish elements are found in the music as well as in the text. The text is comprised of sacred verses from the Golden Age of Spain also known as Siglo de Oro, which occurred from late $15^{\text {th }}$ century until the latter part of the $17^{\text {th }}$ century. The pieces are modal and reflect the Spanish style displaying the modal preference of Phrygian, Major, and harmonic minor scales.

The following is a general interpretation of the verses in order by song:

1. No one, not even God, can move me to love Him for what he can provide such as heaven, but I move to love Him by witness of His pain.

103. This is the only recording as of 2019.

104. The score only indicates it is for soprano.

105. John W. Freeman, "Héctor Campos Paris", cd jacket of Bronx Arts Ensemble, (New York: New World Records, 1989), 4. 
2. It is natural to love Him.

3. As jewels reflect light, so does the light of our souls, which was restored by God so we would not suffer.

4. The stream of God is our peace and joy. We can merge our peace and joy with His as it is all connected.

5. Wake up, and know that you are in charge of your destiny: eternal joy or hellish suffering in eternal death.

I. "No me mueve, ni Dios..."

The first song, "No me mueve, ni Dios", begins with hesitant entrances and truncated motivic elements that appear to be from the theme that will come in later measures. It is interesting to note that the Spanish had often used Phrygian mode, a Flamenco-related scale that sometimes raised the third up a half step. Further analysis shows it may be the first three notes of a Phrygian scale on F.

These peppered thematic fragments continue for fourteen bars before the second idea is introduced. The main melody is stated initially by the oboe. When the voice restates this theme, the final pitch ends up a whole step and continues to unravel in a descending phrase structure. This is in opposition to the oboe's statement of the theme. In contrast, the first time the voice expresses this scale, the third scale degree is altered. In lieu of and Ab, the voice sings an A. This melody is repeated through the movement in both the voice and in the winds.

The oboe introduces the main theme and is echoed by the bassoon. The voice will imitate this melody using the same pitch content. The voice performs the first theme against the winds articulating the second theme of the movement. This interplay can be interpreted in two ways: 1 ) 
as a vocal line with standard accompaniment or 2) the voice and winds are simultaneously stating separate themes.

In sum, Campos Parsi used the secondary thematic material expressed in its entirety between sections or as segmented, transitional material to a new section or tempo. The entire main theme as expressed by the singer is articulated with the same pitches and occurs once by the clarinet. The main theme is used as a sequence, a technique of Bach's that Campos Parsi would improvise in his early years with one of his first piano teachers at church services. A fragment of the secondary theme in Agitato used as a transition to the first theme in the vocal line, and is expressed in what appears to be in G mixolydian, in the first tempo. The wind accompaniment is sparse here until the end where only the bassoon ends on a solitary A pitch, joins the clarinet who is also holding an A.

II "Siguiendo vá..."

The vocal themes are segmented, repeat through each voice, and may occur as a motive in another movement. An example of this is the rhythm on the words, "Siguiendo vá", as found in this second movement of the same name. This rhythmic motive occurs in the opening of the third movement, "O dulces prendas." The first four measures of the second movement are twobar sections with a repeat of each $(2+2+2+2)$ and alternate between AM and AbM. The word "siguiendo" means following or continuing. The continuous accompaniment honors the word right from the beginning. This section is the sound of nature in its natural existence. This is an important element because it likens itself to a character in a drama with its own voice.

The text describes how natural elements go about their business in their own way. The composer uses word painting in a playful manner at times, for example, where the plants grow or 
"cresce" (Figure 3.1); it is expressed in a spray of sixteenths on beat three representing the plants. He also involved the accompaniment in playful expression where the lamb's bray is played in attentive isolation by the oboe. This comical moment is observed with a full rest before continuing with the same thematic material (Figure 3.2).

Figure 3.1 m. 17

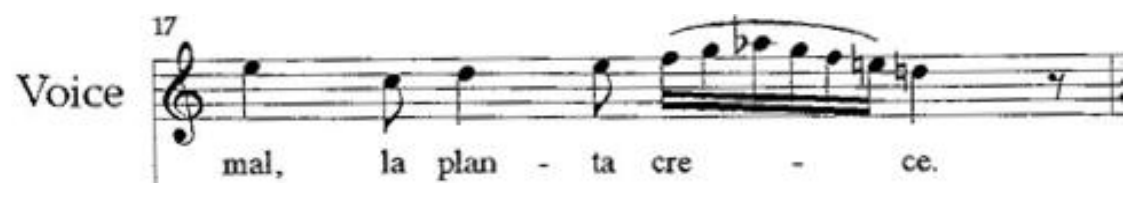

Figure 3.2 m. 23

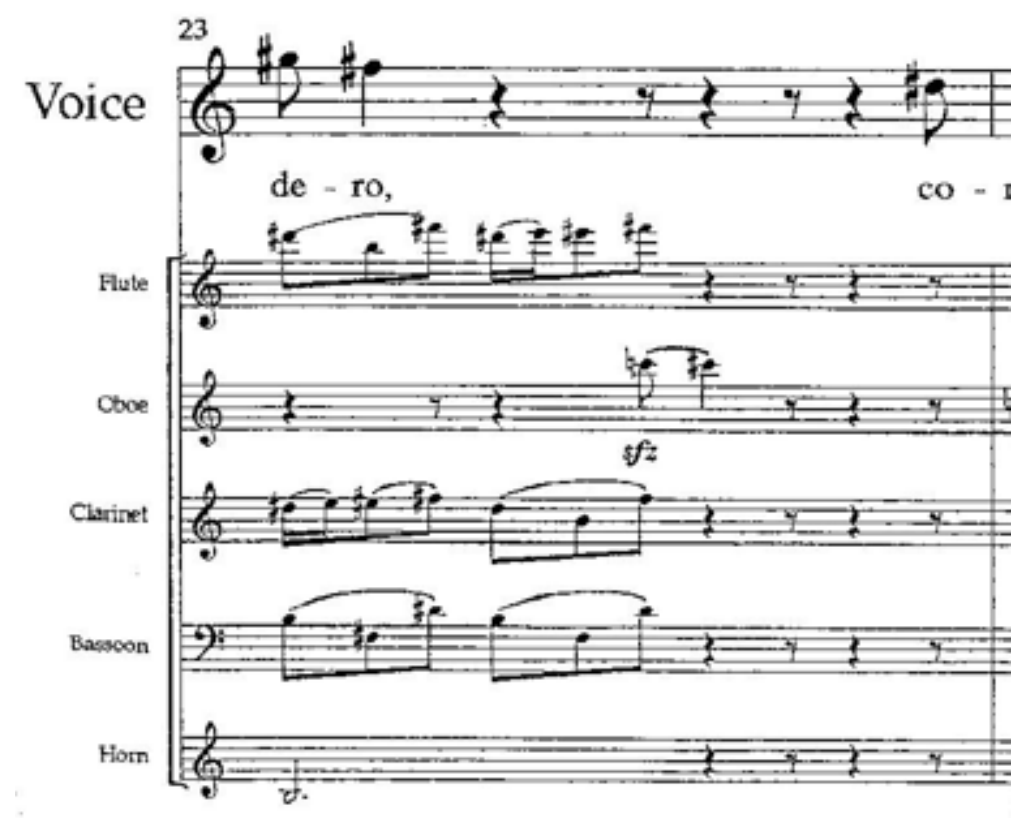

The fermata on the proclamation: "All the things with eternal law follow their nature and the ungrateful man follows his." The voice depicting the ungrateful man opposes the oboe in 
dissonance. The purposeful dissonance concludes with an altered representation of an Andalusian cadence, if in C is: vi - V - IV. ${ }^{106}$

The movement ends as it began expressing the first two measures of the song, but altered and with less texture, omitting the horn and flute. The winds repeat as many times as desired, as indicated in the composition, and continuously "following" as implied by a repeat sign.

This movement demonstrates Spanish cultural influence such as the Andalusian cadence. It is important to remember that this work was an homage to Spain. The cultural expression is enmeshed with contemporary melodies that provide interesting thematic material. The composer's use of the thematic fragmentation is paired with a preview of the next song. This ties the work together from the beginning as a song cycle.

III. “O dulces prendas..."

A twelve-bar flute solo (Figure 3.3), begins the third movement, "O dulces prendas...", and brings to mind the solo wind entrance at the beginning of Debussy's Prelude to the Afternoon of a Faun or in Ravel's Bolero without percussion. These were two composers that Campos Parsi found influential. The flute solo also states part of the previous movement's theme of the words, "Siguiendo vá".

Figure 3.3 Flute solo, excerpt

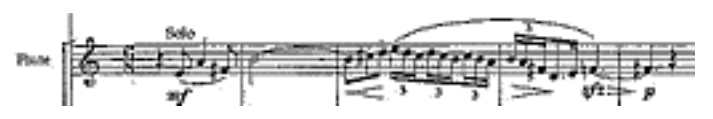

106. While there are variations of the Andalusian cadence, it is based on a descending minor scale. An example of an Andalusian cadence if in C Major, is Dm, CM, B b M, Am. Campos Parsi's treatment of the cadence was prolonged and occurred over several measures. 
As in the previous movement where nature expresses itself in the winds, the oboe solo seems to imply or represent "prendas" or jewels. The singer's words are again represented by the oboe and flute as they wrap around each other on the word "tornadas" which can mean twisted, turned, or transformed. A clarinet solo declares an exploratory, descending passage blending immediately into the singer's words, "Estando yo sin vos", which implies being without a voice. This purposeful dramatization is also painted by the rise of the melody on the word, "alto", meaning high.

Figure 3.4 m. 47-48



The horn communicates against the winds which convey sins before the singer's text that communicates separation from God. The horn, at this moment in m. 48 (Figure 3.4), presents a syncopated rhythm against the flute, clarinet, and bassoon, while the oboe remains silent and apart. The oboe enters when the singer states that she feels her soul, but not as she should. The interval between the singer and the oboe is a tritone apart.

The singer continues with the sentiment that the potential of the spirit was altered. It is of no coincidence that the orchestra suspends a $\mathrm{G}$ minor chord and the oboe expresses an altered 
Phrygian on D. The alteration of a raised third in Phrygian mode is a frequent appearance in his compositions as it was in the music of Spain, and a testament to influence and tribute making a complete circle.

This process is repeated in sequence by a perfect fifth, descending to an $\mathrm{Eb}$, which is sung by the singer on "Pues en una hora, junto me llevastes," ("Well, in an hour, together you took me..."), and in the context of $\mathrm{F}$ half-diminished. The oboe separates itself on the theme of "Siguiendo va", in anticipation of the text "partistes" (you left). It is not until the articulation of the word which means to leave, that the ensemble abandons the voice, which is singing an Eb. The melody in the flute delivered on a quiet promise, "Si ya" (Now that), and it reverses course from its previous departure away from the spirit. The complete realignment of spirit and man occurs in the voice and winds toward the end of the movement.

In sum, this movement contrasts the others because it is more labored, slow, and requires more breath control from the singer. The composer indicated dynamic markings that, when respected and incorporated into performance, can enhance the affect of the text-setting. This is particularly important in ascending, scalar melodies that taper off to a theme carried by the winds. There are no obvious cultural elements in this movement.

IV. "Contento, amore y paz..."

The short fourth song, which translates to contentment, love, and peace, is an exercise in musicianship. Due to the unrelenting meter changes, the stress of the words may fall on an upbeat. This is another indication that the text is subservient to the rhythm like Spanish art songs and arias where the anticipated inflection falls on a different syllable. The syllabic stress on the text can create unnatural variances of inflections over the instrumentalists who are functioning as 
one voice most of the time; The vocal line is also independent of the accompaniment. The voice and winds hand each other fragments of the theme and unify in cadential areas before beginning a new idea. These short bursts are reflected in two to five-note groupings. Toward the end of the movement, the text, "Levantame Señor," foreshadows the poetic content of the final song in this cycle.

Overall, this movement, although brief, shows how the composer took the text and set it in a way as to convey the detached, abrupt one-word utterances of the poem as one would speak them. As the song cycle begins to conclude, Campos Parsi's treatment of the text and thematic material imply a maturity that was not present in his song cycle as discussed earlier in this chapter. This movement can be quite challenging for an ensemble because the singer and winds must communicate well due to disjunct phrases and meter changes. It might be helpful for a singer to treat part of the text like a dry recitative and the more legato sections as accompanied recitative.

V. "Levánta y despierta..."

"Levanta y despierta", begins as a fanfare for the sleeping man. The revelry akin to a bugle's call to action is also pronounced by the singer. The poet asks man to observe the "masa" or material from which he is made. The ensuing word painting on the text inferring creation, is composed of quick, descending sixteenths. The bugle call via the horn in $\mathrm{m}$. 46, implores the sleeping man to wake up (Figure 3.5).

Figure 3.5 m.11-13 voice

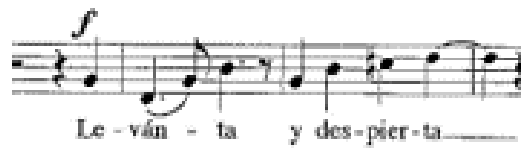


The composer's treatment of the next section is dramatic and honors the weight of the text. Campos Parsi paints the pictures for the landform descriptions depicting steep and uneven paths. More word painting occurs on the word for glory, which takes the voice to the top of the staff when the winds cry caution. The text, "y el mal", is exclaimed before falling on an E minor chord and chromatically descending to a B-natural on "infierno" or hell. A grand pause, like a moment of silence, breaks with an angelic flutter of arpeggiated wings. The flute and clarinet, playing alone, have the interesting effect of an ascending line opposing a descending line. This must be in relation to the text which declares: that man holds the reins in his hands which will take him toward eternal victory or hard death. The composer captures the two paths as a fanfare for victory and to death a descent into Am, G\#m, D\#m9, and utter silence.

A sudden wail, "Llanto" (a wail or cry) on G\# (Figure 3.6), is very similar to the singer's cries in Gitano songs of Spain. This florid passage cascades down into a blaring drone over the flute, oboe, and clarinet playing: B, C, and D. The brief and silent rest is quickly interrupted by the bugle call, "Despierta!", (wake up) at letter J (Figure 3.7). The opening material of this song returns for thirteen measures. It concludes with an ending similar to a Spanish classical guitar at its end, but with his own interpretive twist of an Andalusian cadence: (G)IV6/5 - (C)VII4/3 - (D).

Figure 3.6 Voice, "Llanto”, m. 137-149

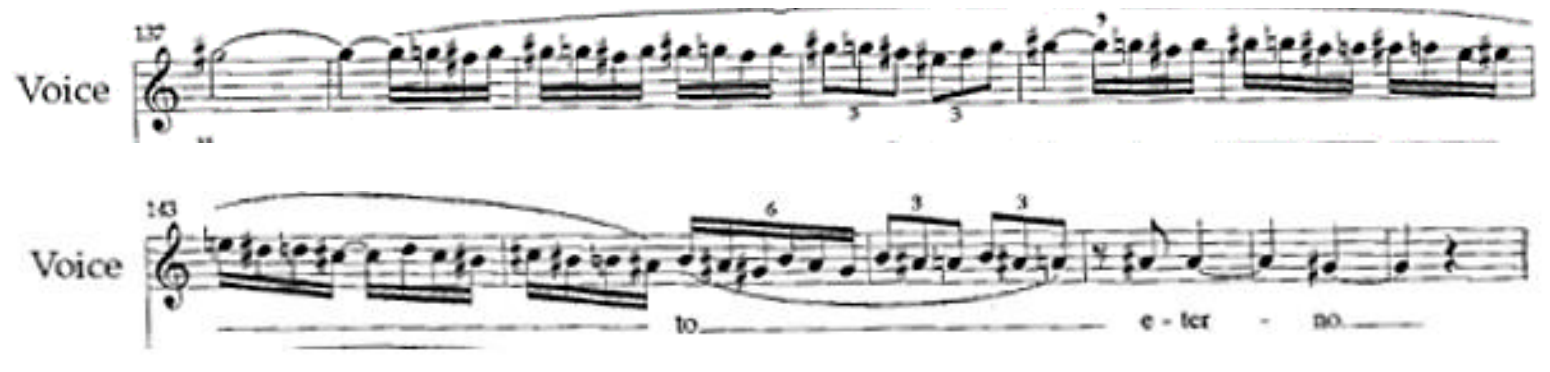


Figure 3.7

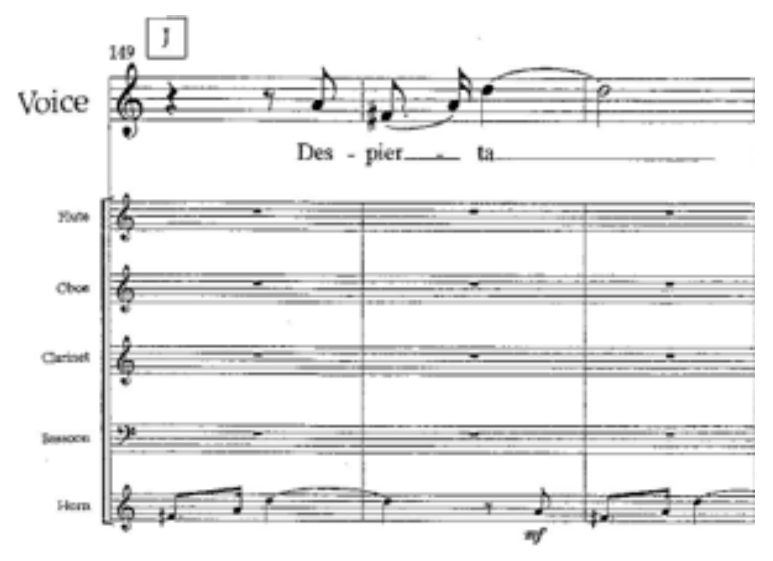

This movement's fanfare is a proper ending to Campos Parsi's most mature vocal work. In comparison to Canciones de Cielo y Agua, Sonetos Sagrados represents a mature compositional style. His growth as a composer is evident in his treatment of themes and in orchestration. The purpose of this work was to honor Puerto Rico's relationship with Spain and therefore, has Spanish elements. Campos Parsi had the advantage of living in Puerto Rico and being exposed to the music of Spain was a cultural advantage to composing these pieces.

The book of sacred text (sonnets) is from the 1930 Anthology of Spanish Verse of the Golden Century. Spanish Language Academy, Madrid, Spain. The common theme among these songs is such that if one believes in and stays connected to God, man can be at peace and enjoy life as it is natural to love Him. Héctor Campos Parsi provided his own translations. Word for word translations are as listed as well as poetic translations. 
A future study including all of his vocal works would benefit singers as they program Puerto Rican vocal literature on their recitals. Campos Parsi composed at least fifteen works for voice. Unfortunately, not all of the literature is available at libraries nor at the Institute of Puerto Rican Culture. Nevertheless, Sonetos Sagrados is the manifestation of years of the conceptualization and synthesis of musical culturalism and his maturity as a trained composer. This song cycle is truly a work of art. The interplay between the vocal line and the winds creates a cantata ${ }^{107}$ as all voices share their personal expression of the messages being conveyed by the poetry.

Sonetos Sagrados is rhythmically and melodically challenging for young singers. They should be approached by a more seasoned musician, preferably a graduate student. The vocal range is appropriate for a soprano with a strong middle voice or a mezzo-soprano whose repertoire includes pieces that normally sit high in her register.

The vocal range of these songs is as follows:

1) "No me mueve, ni Dios... Bb3- Cb5

2) "Siguiendo vá..." C4 - A5

3) "O dulces prendas..." D4 - G5

4) “Contento, amor y paz..." D4 - A5

5) “Levánta y despierta...” B3 - Bb5

The deficiencies that he rectified through his studies, especially in his first year in France, helped him develop tools to express his voice and to allow him to preserve his culture. Campos Parsi employed the use of $20^{\text {th }}$ century techniques from the composers with whom he studied. Some of those elements can be attributed to his teachers at Tanglewood such as Aaron Copland,

107. Freeman, 4. 
Francis Judd Cooke at New England Conservatory of Music, Paul Hindemith at Yale, and in France, Nadia Boulanger and possibly Olivier Messiaen. He also expressed his fondness for Bach, Mozart, Ravel, Debussy, and Bartók.

Influence from Ravel could be seen in the third song, his first song composition, of Canciones de Cielo y Agua, "El Arroyo." Evidence of thematic transformation and fragmentation or kernels may be attributed to composers that influenced his teachers such as Liszt or Beethoven. His earlier life was one of learning via improvisation that created a void that would later be filled by teachers of composition. There is evidence of cultural influence from the music that was being performed on the island, during his childhood, and where the music of Spain had a strong foothold even under US control. These cultural influences included the danza, classical Spanish guitar, and Flamenco music.

The two compositions which are extreme examples of his output over time, reveal that the composer's voice matured in expressivity in conjunction with the development of his compositional tools from 1947-1986. The Puerto Rican danza's influence is most present in the first song of Canciones de Cielo y Agua, "Los Signos en el Cielo," with triplet rhythms falling into consecutive eighth notes in 4/4. An example of this could be seen in his childhood favorite and national anthem, "La Borinqueña," except Campos Parsi extended the third triplet to fill in a $4 / 4$ measure in the B section of the first song as opposed to the national anthem in $2 / 4$.

Setting these two sets of vocal works side by side may seem unfair because Campos Parsi had not completed his training nor resolved his deficiencies by 1947 when he composed Canciones de Cielo y Agua. However, this work serves as a repository for his earliest style, choices, and poetic voice. Sonetos Sagrados serves as a testament to his maturity and conclusion of experimentation and search for a musical identity. This work is a representation of early 
cultural influences from his youth and all that he learned, digested, and processed in his former works. In it are the elements that he had to curtail in order to study the neoclassical characteristics Nadia Boulanger had taught him. It was after his exposure to John Cage and Edgar Varèse that he felt his voice come to the forefront. By 1986, this voice was strong and unapologetic. His use of color and timbre as elements of form were what he had been seeking from the beginning, but he did not have the musical tools to express that. ${ }^{108}$

In Donald Thompson's review of a performance of Sonetos Sagrados at the Inter-

American Arts Festival in Puerto Rico, he wrote:

This was by far the most extended work on the program and I [sic] think the most successful, all considered. I believe that Campos in his mature wisdom has decided to steer clear of today's musical fads and fashions (even if it were possible to find out what they are) and simply write some music. Campos knows and respects the human voice, and his songs are in fact one his most engaging works. Here, he skillfully combines the voice with wind ensemble, and the result is a gracious by no means easy addition to his extensive varied catalogue of compositions. ${ }^{109}$

108. Fernando Caso 1972 Thesis, 98, 110. Héctor Campos Parsi gave a private interview on January 25, 1972, Santurce, Puerto Rico, expressing this sentiment.

109. Donald Thompson and Francis Schwartz. Concert Life in Puerto Rico, 1957-1992: Views and Reviews, (University of Puerto Rico: San Juan, P.R., 1998), 537. 


\section{A Note on Diction and Interpretation}

Canciones de Cielo y Agua can be sung by younger voices because the range is not excessive nor are the rhythms that complicated. The vocal line is often scalar and do not have extreme ranges. In contract, Sonetos Sagrados are complicated for singer and wind ensemble. These rhythms and melodies are complex and each have a large range with difficult pitches to accommodate such as ascending lines to piano. The former work is somewhat inaccessible, but is available if you search the Institute of Culture in Puerto Rico or the Barcelona Library. Sonetos Sagrados is available in many US libraries.

A singer may wonder what diction strategy to employ regarding the language. A nativeSpanish speaker from Puerto Rico or of Puerto-Rican descent will have a different approach than another from a different Latin American or Iberian region. While the choice is up to the singer, the information regarding the composer, the author of the text, and the nature of the piece should help guide the singer to make an appropriate interpretation. If, for example, in Sonetos Sagrados, the singer notes that the composer is Puerto Rican, but the text is from Spain, the singer may choose either country's approach to diction. The text serves as an homage from a Puerto Rican composer, and one may interpret it with appropriate diction. 
Translations

Canciones de Cielo y Agua ${ }^{110}$

Table 3.1 I. "Los signos en el cielo"

\begin{tabular}{|c|c|c|}
\hline Original Text & Word for Word Translation & Poetic Translation \\
\hline ¡Ay! Los signos en el cielo & (Ah! The signs in sky) & Ah! The signs in sky. \\
\hline $\begin{array}{l}\text { Las nubes se cierran sobre el } \\
\text { sol }\end{array}$ & $\begin{array}{l}\text { (The clouds they close over } \\
\text { the sun) }\end{array}$ & The clouds cover the sun. \\
\hline $\begin{array}{l}\text { La luz esconde detrás del } \\
\text { negror }\end{array}$ & $\begin{array}{l}\text { (The light hides behind the } \\
\text { dark) }\end{array}$ & $\begin{array}{l}\text { The light hides behind the } \\
\text { darkness. }\end{array}$ \\
\hline $\begin{array}{l}\text { Y en el viento qué alsa su } \\
\text { cola sin piedad }\end{array}$ & $\begin{array}{l}\text { (And in the wind that raises } \\
\text { its tail without pity) }\end{array}$ & $\begin{array}{l}\text { And in the wind which } \\
\text { raises its tail without mercy. }\end{array}$ \\
\hline Arrastrando va mi corazón & (Dragging goes my heart) & Dragging goes my heart \\
\hline Esta pena de un amor & (This pity of a love) & This dejection from a love \\
\hline $\begin{array}{l}\text { Yen las nubes hay una } \\
\text { marca de dolor } \\
\text { Los signos de llanto y de } \\
\text { pasión }\end{array}$ & $\begin{array}{l}\text { (And in the clouds have a } \\
\text { mark of pain) } \\
\text { (The signs of cries and of } \\
\text { passion) }\end{array}$ & $\begin{array}{l}\text { And in the clouds there is a } \\
\text { mark of pain } \\
\text { The signs of crying and of } \\
\text { passion }\end{array}$ \\
\hline $\begin{array}{l}\text { Qué agarrótan a mis ojos } \\
\text { doloridos de estar solos }\end{array}$ & $\begin{array}{l}\text { (What seize so much to my } \\
\text { eyes pained to be alone) }\end{array}$ & $\begin{array}{l}\text { that stiffen my pained eyes } \\
\text { from being alone }\end{array}$ \\
\hline [repeats beginning text] & & \\
\hline
\end{tabular}

110. The poetry lacks most conventions with the exception of exclamation points and question marks. 
Table 3.2 II "El Aguacero"

\begin{tabular}{|c|c|c|}
\hline Original Text & Word for Word Translation & Poetic Translation \\
\hline $\begin{array}{l}\text { Qué húmeda queda la tierra } \\
\text { luego del gran aguacero }\end{array}$ & $\begin{array}{l}\text { What humidity stays the } \\
\text { earth after the great } \\
\text { downpour) }\end{array}$ & $\begin{array}{l}\text { How wet stays the earth } \\
\text { after the great downpour }\end{array}$ \\
\hline $\begin{array}{l}\text { cuando se derrama el cielo } \\
\text { sobre el lomo de la sierra }\end{array}$ & $\begin{array}{l}\text { (when it spills the sky over } \\
\text { the hill / back of the } \\
\text { mountains) }\end{array}$ & $\begin{array}{l}\text { when the sky pours out } \\
\text { over the back of the } \\
\text { mountains }\end{array}$ \\
\hline $\begin{array}{l}\text { Y en el verde de las hojas } \\
\text { y en el aroma del suelo }\end{array}$ & $\begin{array}{l}\text { (And in the green of the } \\
\text { leaves and in the scent of the } \\
\text { ground) }\end{array}$ & $\begin{array}{l}\text { And in the green of the } \\
\text { leaves and in the scent of the } \\
\text { earth }\end{array}$ \\
\hline $\begin{array}{l}\text { me va llegando consuelo } \\
\text { a mí más grande congoja }\end{array}$ & $\begin{array}{l}\text { (to me comes arriving } \\
\text { confort to my most big) }\end{array}$ & $\begin{array}{l}\text { I am receiving comfort } \\
\text { to my greater grief }\end{array}$ \\
\hline $\begin{array}{l}\text { pues se ha ido mi cariño } \\
\text { junto con el aguacero }\end{array}$ & $\begin{array}{l}\text { (then it has my dear one } \\
\text { together with the downpour) }\end{array}$ & $\begin{array}{l}\text { well my dear one has left } \\
\text { together with the downpour. }\end{array}$ \\
\hline $\begin{array}{l}\text { En cada gota de lluvia } \\
\text { se va un trozo de mi alma }\end{array}$ & $\begin{array}{l}\text { (In each drop of rain, it goes } \\
\text { a piece of my soul) }\end{array}$ & $\begin{array}{l}\text { In each drop of rain a piece } \\
\text { of my soul leaves, }\end{array}$ \\
\hline $\begin{array}{l}\text { ya no sabré de más calma } \\
\text { que dolor que va en el agua }\end{array}$ & $\begin{array}{l}\text { (already not know I of more } \\
\text { calm, what pain that goes in } \\
\text { the water) }\end{array}$ & $\begin{array}{l}\text { I will not know of more } \\
\text { calm, such pain that goes } \\
\text { into the water. }\end{array}$ \\
\hline $\begin{array}{l}\text { Y en la bruma levantada } \\
\text { sobre la más vieja loma }\end{array}$ & $\begin{array}{l}\text { (And in the mist raised over } \\
\text { the most old hill) }\end{array}$ & $\begin{array}{l}\text { And in the rising mist over } \\
\text { the old mountain, }\end{array}$ \\
\hline $\begin{array}{l}\text { perdida hav'una paloma } \\
\text { maltratada y muy cansada }\end{array}$ & $\begin{array}{l}\text { (lost there is a dove, } \\
\text { mistreated and very tired) }\end{array}$ & $\begin{array}{l}\text { there is a lost dove, } \\
\text { mistreated and very tired, }\end{array}$ \\
\hline $\begin{array}{l}\text { es mi alma atribulada } \\
\text { persiguiendo tu crucero }{ }^{111} \text {. }\end{array}$ & $\begin{array}{l}\text { (is my soul troubled, } \\
\text { following your *voyage) }\end{array}$ & $\begin{array}{l}\text { it is my troubled soul, } \\
\text { continuing your voyage. }\end{array}$ \\
\hline
\end{tabular}

111. Crucero translates to cruise, crossroads, and cross depending on the interpretation. Voyage is implied as a sea journey like a cruise as the work is about water. 
Table 3.3 III "El Arroyo"

\begin{tabular}{|c|c|c|}
\hline Original Text & Word for Word Translation & Poetic Translation \\
\hline $\begin{array}{l}\text { Cómo el agua qué enredada } \\
\text { va }\end{array}$ & $\begin{array}{l}\text { (How the water that } \\
\text { entangled goes) }\end{array}$ & How tangled goes the water. \\
\hline $\begin{array}{l}\text { a los rosarios de las piedras } \\
\text { grises }\end{array}$ & $\begin{array}{l}\text { (to the rosary of the rocks } \\
\text { gray) }\end{array}$ & $\begin{array}{l}\text { to the rosary / prayer of the } \\
\text { gray rocks, }\end{array}$ \\
\hline va bordando mi triste cantar & $\begin{array}{l}\text { (goes embroidering my sad } \\
\text { singing) }\end{array}$ & $\begin{array}{l}\text { My sad singing is stitched } \\
\text { into }\end{array}$ \\
\hline Un arroyo de caminos tristes & (A stream of paths sad) & A stream of sad paths \\
\hline $\begin{array}{l}\text { y en el cauce estrecho de su } \\
\text { andar }\end{array}$ & $\begin{array}{l}\text { (and in the riverbed narrow } \\
\text { of its walk) }\end{array}$ & $\begin{array}{l}\text { and in the movement of the } \\
\text { narrow riverbed }\end{array}$ \\
\hline $\begin{array}{l}\text { hay un cuento de lágrimas } \\
\text { verdes }\end{array}$ & $\begin{array}{l}\text { (there is a tale of tears } \\
\text { green) }\end{array}$ & there is a story of green tears \\
\hline $\begin{array}{l}\text { lágrimas que ya lloraron mis } \\
\text { ojos por tu mal }\end{array}$ & $\begin{array}{l}\text { (tears that already cried my } \\
\text { eyes for your evil) }\end{array}$ & $\begin{array}{l}\text { tears that have already cried } \\
\text { from your evil-doing }\end{array}$ \\
\hline $\mathrm{Y}$ al ver yo las aguas correr & $\begin{array}{l}\text { (And the see I the waters } \\
\text { run) }\end{array}$ & And to see those waters run \\
\hline saltando por entre los juncos & (Jumping between the reeds) & $\begin{array}{l}\text { Jumping in between the } \\
\text { reeds, }\end{array}$ \\
\hline $\begin{array}{l}\text { en mis manos se quiebra un } \\
\text { querer }\end{array}$ & $\begin{array}{l}\text { (in my hands breaks a } \\
\text { desire) }\end{array}$ & $\begin{array}{l}\text { and a wish breaks in my } \\
\text { hands }\end{array}$ \\
\hline $\begin{array}{l}\text { mis labios se quedan muy } \\
\text { juntos }\end{array}$ & $\begin{array}{l}\text { (my lips they stay very } \\
\text { together) }\end{array}$ & my lips stay together. \\
\hline $\begin{array}{l}\text { Cómo el agua qué enredada } \\
\text { va }\end{array}$ & $\begin{array}{l}\text { (How the water that } \\
\text { entangled goes) }\end{array}$ & How tangled goes the water. \\
\hline $\begin{array}{l}\text { A los troncos serca del la } \\
\text { orilla }\end{array}$ & $\begin{array}{l}\text { (To the logs close to the } \\
\text { edge) }\end{array}$ & $\begin{array}{l}\text { Toward the logs close to the } \\
\text { edge, }\end{array}$ \\
\hline Amarado a ti va mi existir & $\begin{array}{l}\text { (tied to you goes my } \\
\text { existence) }\end{array}$ & My existence is tied to yours \\
\hline
\end{tabular}


Table 3.3 Continued III "El Arroyo"

\begin{tabular}{|c|c|c|}
\hline y no conozco de otra vida & $\begin{array}{l}\text { (and not recognize of } \\
\text { another life) }\end{array}$ & $\begin{array}{l}\text { and I do not another way to } \\
\text { live }\end{array}$ \\
\hline Y como el Arroyo yo soy & (And how the stream I am) & $\begin{array}{l}\text { And since I am the like the } \\
\text { stream }\end{array}$ \\
\hline $\begin{array}{l}\text { en marcha constante a la } \\
\text { muerte }\end{array}$ & $\begin{array}{l}\text { (in march constant to the } \\
\text { death) }\end{array}$ & $\begin{array}{l}\text { consistently marching } \\
\text { toward death }\end{array}$ \\
\hline $\begin{array}{l}\text { Hacía el mar que sabe } \\
\text { recibir }\end{array}$ & $\begin{array}{l}\text { (to the sea that knows } \\
\text { receive) }\end{array}$ & $\begin{array}{l}\text { Toward the sea that knows } \\
\text { how to receive }\end{array}$ \\
\hline Aquellos de la pena fuerte, & (Those of the pity strong) & Those of strong sorrow \\
\hline Tristes aguas, aguas tristes. & (Sad waters, waters, sad.) & $\begin{array}{l}\text { Waters of sadness, sad } \\
\text { waters. }\end{array}$ \\
\hline
\end{tabular}




\section{Sonetos Sagrados}

Table 3.4 I. "No me mueve, ni Dios" (Attributed to St. Theresa of Avila)

\begin{tabular}{|c|c|c|}
\hline Original Text & Word for Word Translation & ${ }^{112}$ Poetic Translation \\
\hline $\begin{array}{l}\text { No me mueve, ni Dios para } \\
\text { quererte, }\end{array}$ & $\begin{array}{l}\text { (don't me move not God to } \\
\text { love you) }\end{array}$ & $\begin{array}{l}\text { Don't move me, my God, to } \\
\text { love you. }\end{array}$ \\
\hline $\begin{array}{l}\text { el cielo que me tienes } \\
\text { prometido, }\end{array}$ & $\begin{array}{l}\text { (the sky that me has } \\
\text { promised) }\end{array}$ & $\begin{array}{l}\text { The heaven that you have } \\
\text { promised, }\end{array}$ \\
\hline $\begin{array}{l}\text { ni me mueve el infierno tan } \\
\text { temido }\end{array}$ & $\begin{array}{l}\text { (nor me move the hell so } \\
\text { feared) }\end{array}$ & $\begin{array}{l}\text { Nor am I moved by dreadful } \\
\text { hell }\end{array}$ \\
\hline $\begin{array}{l}\text { para dejar por eso de } \\
\text { ofenderte. }\end{array}$ & $\begin{array}{l}\text { (for leave over that to offend } \\
\text { you) }\end{array}$ & $\begin{array}{l}\text { to dismiss that to not offend } \\
\text { you. }\end{array}$ \\
\hline $\begin{array}{l}\text { Tu me muevas Señor, } \\
\text { muéveme el verte }\end{array}$ & $\begin{array}{l}\text { (You me move Lord, move } \\
\text { me the see) }\end{array}$ & $\begin{array}{l}\text { You move me Lord, move } \\
\text { me to see you }\end{array}$ \\
\hline $\begin{array}{l}\text { Clavado en una cruz y } \\
\text { escarnecido. }\end{array}$ & $\begin{array}{l}\text { (nailed on a cross and } \\
\text { *mocked) }\end{array}$ & $\begin{array}{l}\text { Nailed to a cross and } \\
\text { *mocked. }\end{array}$ \\
\hline $\begin{array}{l}\text { Muéveme ver tu cuerpo tan } \\
\text { herido }\end{array}$ & $\begin{array}{l}\text { (move me see your body so } \\
\text { injured) }\end{array}$ & $\begin{array}{l}\text { Move me to see your body } \\
\text { so injured. }\end{array}$ \\
\hline $\begin{array}{l}\text { Muéveme tus afrentas y tu } \\
\text { muerte. }\end{array}$ & $\begin{array}{l}\text { (move me your offense and } \\
\text { your death) }\end{array}$ & $\begin{array}{l}\text { Move me, your offense and } \\
\text { your death. }\end{array}$ \\
\hline $\begin{array}{l}\text { Muéveme, al fin, tu amor de } \\
\text { tal manera }\end{array}$ & $\begin{array}{l}\text { (move me, at last, your love } \\
\text { of such way) }\end{array}$ & $\begin{array}{l}\text { Move me, at last, your love } \\
\text { in such a way }\end{array}$ \\
\hline $\begin{array}{l}\text { que aunque no hubiera cielo, } \\
\text { yo te amara }\end{array}$ & $\begin{array}{l}\text { (that even though not would } \\
\text { have heaven, I to you love) }\end{array}$ & $\begin{array}{l}\text { that even if there were no } \\
\text { heaven, I would love you. }\end{array}$ \\
\hline $\begin{array}{l}\text { y aunque no hubiera } \\
\text { infierno, te temeria. }\end{array}$ & $\begin{array}{l}\text { (and even though not would } \\
\text { have hell, to you fear) }\end{array}$ & $\begin{array}{l}\text { and even if there no hell, I } \\
\text { would fear you. }\end{array}$ \\
\hline $\begin{array}{l}\text { No me tienes que dar porque } \\
\text { te quiera }\end{array}$ & $\begin{array}{l}\text { (no to me have that give } \\
\text { because to you love) }\end{array}$ & $\begin{array}{l}\text { You do not have to justify } \\
\text { why I should love you. }\end{array}$ \\
\hline $\begin{array}{l}\text { pues aunque lo que espero, } \\
\text { no esperara, }\end{array}$ & $\begin{array}{l}\text { (well even though which } \\
\text { that wait, not wait) }\end{array}$ & $\begin{array}{l}\text { And if though I wait for it, I } \\
\text { will not await it. }\end{array}$ \\
\hline
\end{tabular}

112 These poetic translations are interpreted from those provided by Héctor Campos Parsi at the end of the score. 


\begin{tabular}{|l|l|l}
\hline $\begin{array}{l}\text { lo mismo que te quiero, te } \\
\text { quisiera. }\end{array}$ & $\begin{array}{l}\text { (the same that to you love, } \\
\text { to you I would like) }\end{array}$ & $\begin{array}{l}\text { the same way I love you, I } \\
\text { want you. }\end{array}$
\end{tabular}
quisiera. to you I would like) 
Table 3.5 II "Siguiendo vá" (Alfonso de Bonilla, 1617)

\begin{tabular}{|c|c|c|}
\hline Original Text & Word for Word Translation & Poetic Translation \\
\hline Siguiendo vá su natural porfía & $\begin{array}{l}\text { (following goes its natural } \\
\text { purpose) }\end{array}$ & It follows its natural purpose \\
\hline $\begin{array}{l}\text { la piedra hasta el centro que } \\
\text { apetece, }\end{array}$ & $\begin{array}{l}\text { (the rock until the center that } \\
\text { to feel like) }\end{array}$ & $\begin{array}{l}\text { The rock even feels hard at the } \\
\text { center }\end{array}$ \\
\hline el aire puro seca y humedece, & $\begin{array}{l}\text { (the air pure dry and } \\
\text { humidifying) }\end{array}$ & the air, pure and dry, moistens \\
\hline $\begin{array}{l}\text { el fuego dá calor, el agua, } \\
\text { enfría. }\end{array}$ & $\begin{array}{l}\text { (the fire gives heat, and water, } \\
\text { cools) }\end{array}$ & $\begin{array}{l}\text { the fire gives off heat, the water, } \\
\text { cools }\end{array}$ \\
\hline $\begin{array}{l}\text { La presencia del sol, engendra } \\
\text { el día, }\end{array}$ & $\begin{array}{l}\text { (The presence of sun, } \\
\text { produces the day) }\end{array}$ & $\begin{array}{l}\text { The presence of the sun, creates } \\
\text { the day }\end{array}$ \\
\hline $\begin{array}{l}\text { levanta el vuelo el ave }{ }^{113} \text {, } \\
\text { nada el pesce, }\end{array}$ & $\begin{array}{l}\text { (lift the flight the bird, swims } \\
\text { the fish) }\end{array}$ & $\begin{array}{l}\text { Life the flight to the bird, swims } \\
\text { the fish }\end{array}$ \\
\hline $\begin{array}{l}\text { anda todo animal, la planta } \\
\text { crece. }\end{array}$ & $\begin{array}{l}\text { (walks all animal, the plant } \\
\text { grows) }\end{array}$ & $\begin{array}{l}\text { All animals walk, the plant } \\
\text { grows. }\end{array}$ \\
\hline $\begin{array}{l}\text { La piedra imán levanta, el } \\
\text { norte guía, }\end{array}$ & $\begin{array}{l}\text { (the rock magnet lift, the } \\
\text { north guide) }\end{array}$ & $\begin{array}{l}\text { The magnetic rock lifts, the } \\
\text { north guides }\end{array}$ \\
\hline $\begin{array}{l}\text { bufa el pesado buey, bala el } \\
\text { cordero, }\end{array}$ & $\begin{array}{l}\text { (spits the heavy ox, bleats the } \\
\text { lamb) }\end{array}$ & $\begin{array}{l}\text { the heavy ox spits, the lamb } \\
\text { bleats, }\end{array}$ \\
\hline $\begin{array}{l}\text { conoce al dueño, el can por el } \\
\text { olfato, }\end{array}$ & $\begin{array}{l}\text { (know the owner, the dog for } \\
\text { the smell) }\end{array}$ & $\begin{array}{l}\text { The dog knows the owner by his } \\
\text { scent, }\end{array}$ \\
\hline $\begin{array}{l}\text { el caballo relincha, el león } \\
\text { brama. }\end{array}$ & $\begin{array}{l}\text { (the horse neighs, the lion } \\
\text { roars) }\end{array}$ & the horse neighs, the lion roars \\
\hline $\begin{array}{l}\text { Todas las cosas con eterno } \\
\text { fuero }\end{array}$ & $\begin{array}{l}\text { (all the things with eternal } \\
\text { law) }\end{array}$ & All things with eternal law \\
\hline $\begin{array}{l}\text { siguen su natural; y el hombre } \\
\text { ingrato, }\end{array}$ & $\begin{array}{l}\text { (follow their nature and the } \\
\text { man ungrateful) }\end{array}$ & $\begin{array}{l}\text { follow their nature; and the } \\
\text { ungrateful man }\end{array}$ \\
\hline $\begin{array}{l}\text { no sigue el suyo, pués a Dios } \\
\text { no ama. }\end{array}$ & $\begin{array}{l}\text { (does not follow his own } \\
\text { since to God does not love) }\end{array}$ & $\begin{array}{l}\text { doesn't follow his own, since he } \\
\text { does not love God. }\end{array}$ \\
\hline
\end{tabular}

113. Double meanings AVE and PESCE: Ave meaning bird or praise to the saints Pesce from the Latin word, Pisces, meaning fish 
Table 3.6 III. "O dulces prendas” (Sebastián de Córdoba, 1505)

\begin{tabular}{|c|c|c|}
\hline Original Text & Word for Word Translation & Poetic Translation \\
\hline $\begin{array}{l}\text { O dulces prendas, por mi } \\
\text { bien tornadas }\end{array}$ & $\begin{array}{l}\text { (or sweet garments } \\
\text { /tokens/gifts, for my good } \\
\text { returns) }\end{array}$ & $\begin{array}{l}\text { Or sweet gifts that for my } \\
\text { sake return }\end{array}$ \\
\hline $\begin{array}{l}\text { dulces y alegres para el alma } \\
\text { mía. }\end{array}$ & $\begin{array}{l}\text { (sweet and joyous for the } \\
\text { soul mine) }\end{array}$ & sweet and joyous to my soul. \\
\hline $\begin{array}{l}\text { Estando yo sin vos ¿Cómo } \\
\text { vivía, }\end{array}$ & $\begin{array}{l}\text { (Being me without you. } \\
\text { How I lived?) }\end{array}$ & $\begin{array}{l}\text { Being without you. How did } \\
\text { I live }\end{array}$ \\
\hline $\begin{array}{l}\text { prendas del alto cielo, } \\
\text { derivadas? }\end{array}$ & $\begin{array}{l}\text { (tokens / gifts / garments } \\
\text { from high heavens, } \\
\text { derivatives) }\end{array}$ & gifts from high heaven? \\
\hline $\begin{array}{l}\text { Mis culpas os pierdieron y } \\
\text { apartada }\end{array}$ & $\begin{array}{l}\text { (my faults you they have } \\
\text { lost and to move away) }\end{array}$ & $\begin{array}{l}\text { You cast away and removed } \\
\text { my faults }\end{array}$ \\
\hline $\begin{array}{l}\text { el alma, aunque animaba, no } \\
\text { sentía, }\end{array}$ & $\begin{array}{l}\text { (the soul, although me } \\
\text { animated, did not I felt) }\end{array}$ & $\begin{array}{l}\text { the soul, although lively, I } \\
\text { could not feel it, }\end{array}$ \\
\hline sentía pero no como debí & $\begin{array}{l}\text { (I felt it but not how I should } \\
\text { have) }\end{array}$ & $\begin{array}{l}\text { I felt it, but not how I should } \\
\text { have }\end{array}$ \\
\hline $\begin{array}{l}\text { que estaban sus potencias } \\
\text { alteradas. }\end{array}$ & $\begin{array}{l}\text { (that were their potential } \\
\text { altered) }\end{array}$ & $\begin{array}{l}\text { since their potential was } \\
\text { altered. }\end{array}$ \\
\hline $\begin{array}{l}\text { Pues en una hora, junto me } \\
\text { llevastes, }\end{array}$ & $\begin{array}{l}\text { (then in one / an hour, } \\
\text { together me you took) }\end{array}$ & $\begin{array}{l}\text { Then in an hour, you took } \\
\text { me together with you }\end{array}$ \\
\hline $\begin{array}{l}\text { por mi todo bíen, cuando } \\
\text { partistes }\end{array}$ & $\begin{array}{l}\text { (for me all good, when you } \\
\text { left) }\end{array}$ & $\begin{array}{l}\text { for my own good, when you } \\
\text { left }\end{array}$ \\
\hline $\begin{array}{l}\text { si ya por la bondad de Dios, } \\
\text { volvistes }\end{array}$ & $\begin{array}{l}\text { (since already for the } \\
\text { goodness of God, you } \\
\text { returned) }\end{array}$ & $\begin{array}{l}\text { If by the goodness of God, } \\
\text { you returned }\end{array}$ \\
\hline $\begin{array}{l}\text { no os aparteis del alma que } \\
\text { sanastes, } \\
\text { porqué no muera, entre } \\
\text { dolores tristes }\end{array}$ & $\begin{array}{l}\text { (no you apart from the soul } \\
\text { that you healed) } \\
\text { (because does not it die, } \\
\text { within pains sad) }\end{array}$ & $\begin{array}{l}\text { do not separate from your } \\
\text { healed soul, } \\
\text { because it does not die in } \\
\text { anguish. }\end{array}$ \\
\hline
\end{tabular}


Table 3.7 IV. "Contento, amor y paz" (Gregorio Silvestre, 1502)

\begin{tabular}{|c|c|c|}
\hline Original Text & Word for Word Translation & Poetic Translation \\
\hline $\begin{array}{l}\text { Contento, amor y paz, gloria } \\
\text { y consuelo, }\end{array}$ & $\begin{array}{l}\text { (contentment, love and } \\
\text { peace, glory and comfort) }\end{array}$ & $\begin{array}{l}\text { contentment, love and } \\
\text { peace, glory and comfort. }\end{array}$ \\
\hline $\begin{array}{l}\text { descanso y quietud del alma } \\
\text { mía, }\end{array}$ & $\begin{array}{l}\text { (rest and stillness of soul } \\
\text { mine) }\end{array}$ & rest and stillness of my soul, \\
\hline $\begin{array}{l}\text { refugio, amparo, ardor dulce } \\
\text { alegría, }\end{array}$ & $\begin{array}{l}\text { (refuge, protection, burning } \\
\text { sweet joy) }\end{array}$ & $\begin{array}{l}\text { refuge, protection, burning } \\
\text { sweet joy, }\end{array}$ \\
\hline $\begin{array}{l}\text { Espejo, vida, luz, norte y } \\
\text { modelo, }\end{array}$ & $\begin{array}{l}\text { (mirror, life, light, north and } \\
\text { model) }\end{array}$ & $\begin{array}{l}\text { Mirror, life, light, north and } \\
\text { model, }\end{array}$ \\
\hline lucero, luna, sol y claro día. & $\begin{array}{l}\text { (star, moon, sun and clear } \\
\text { day.) }\end{array}$ & $\begin{array}{l}\text { star, moon, sun and clear } \\
\text { day. }\end{array}$ \\
\hline $\begin{array}{l}\text { Sabrosa, celestial, dulce } \\
\text { armonía, }\end{array}$ & $\begin{array}{l}\text { (delicious, heavenly, sweet } \\
\text { harmony) }\end{array}$ & $\begin{array}{l}\text { Delicious, heavenly, sweet } \\
\text { harmony, }\end{array}$ \\
\hline $\begin{array}{l}\text { refugio y rendencíon de los } \\
\text { del suelo. }\end{array}$ & $\begin{array}{l}\text { (refuge and redemption of } \\
\text { those of the ground / earth) }\end{array}$ & $\begin{array}{l}\text { refuge and redemption of } \\
\text { those of the earth. }\end{array}$ \\
\hline $\begin{array}{l}\text { Eterno, inconmutable, } \\
\text { omnipotente de gracia, }\end{array}$ & $\begin{array}{l}\text { (eternal, unchanging, } \\
\text { omnipotent of grace) }\end{array}$ & $\begin{array}{l}\text { Eternal, unchanging, } \\
\text { omnipotence of grace, }\end{array}$ \\
\hline $\begin{array}{l}\text { de virtud, y santo cielo, } \\
\text { profundo amor, }\end{array}$ & $\begin{array}{l}\text { (of virtue, and blessed } \\
\text { heaven, profound love) }\end{array}$ & $\begin{array}{l}\text { of virtue, and blessed } \\
\text { heaven, profound love, }\end{array}$ \\
\hline $\begin{array}{l}\text { incansable fuente, levántame } \\
\text { Señor, }\end{array}$ & $\begin{array}{l}\text { (tireless source, lift me up } \\
\text { Lord) }\end{array}$ & $\begin{array}{l}\text { tireless source, lift me up } \\
\text { Lord, }\end{array}$ \\
\hline álzame el vuelo, & (raise me the flight) & Raise me into flight \\
\hline $\begin{array}{l}\text { que vaya yo a gozar de tu } \\
\text { corriente, }\end{array}$ & $\begin{array}{l}\text { (that go I to delight of your } \\
\text { current / stream) }\end{array}$ & $\begin{array}{l}\text { so that I will go and delight } \\
\text { of your stream }\end{array}$ \\
\hline $\begin{array}{l}\text { contento, amor y paz, gloria } \\
\text { y consuelo. }\end{array}$ & $\begin{array}{l}\text { (contentment, love and } \\
\text { peace, glory and comfort) }\end{array}$ & $\begin{array}{l}\text { contentment, love and } \\
\text { peace, glory and comfort. }\end{array}$ \\
\hline
\end{tabular}


Table 3.8 V. "Levánta y despierta” (Gregorio Silvestre, 1502)

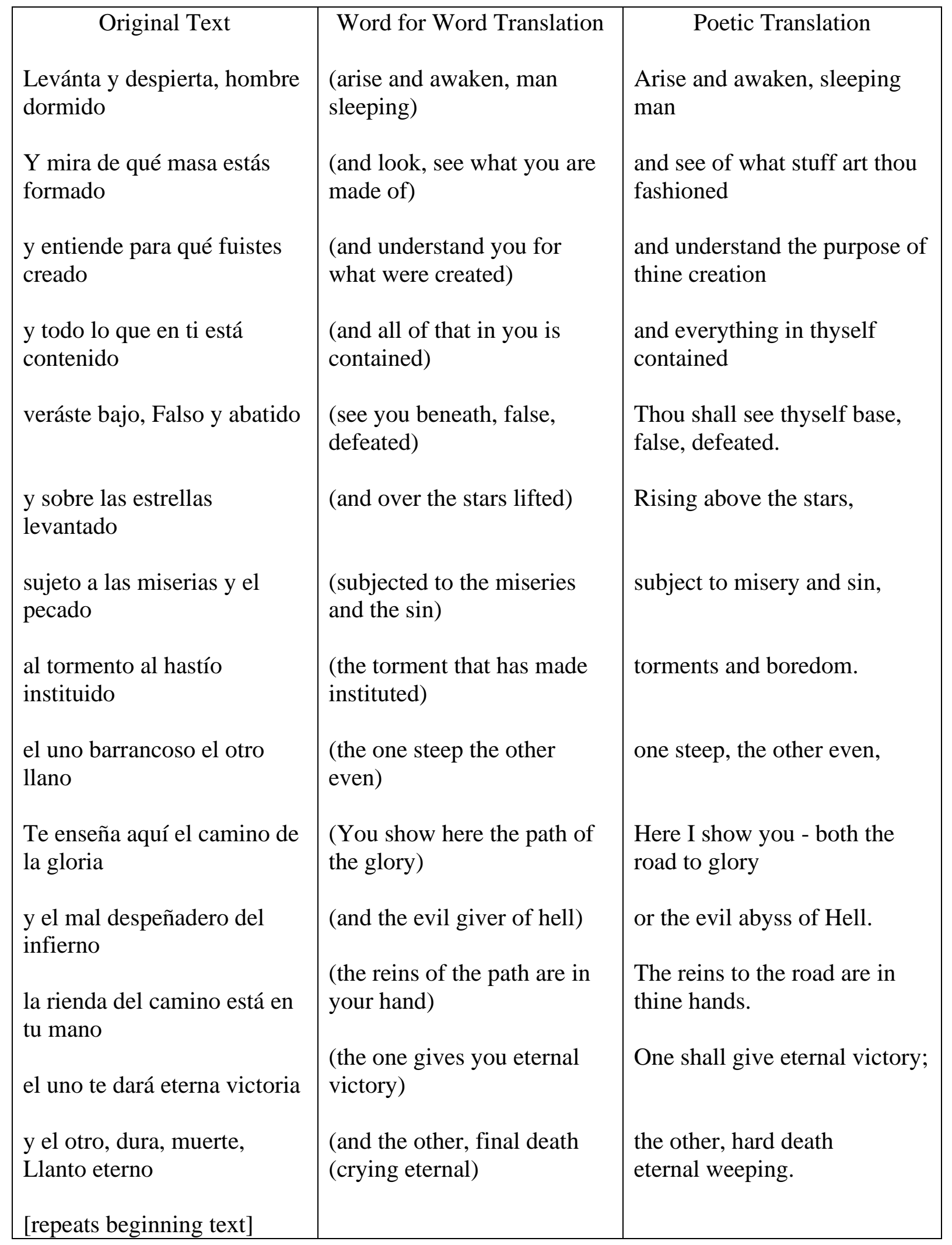




\section{CHAPTER 4: CONCLUSION}

Campos Parsi purposefully chose his style of composition based on what he valued in his culture which was through the process of enculturation, which “...refers to the process by which the individual learns his culture, and it must be emphasized that this is a never-ending process continuing throughout the life span of the individual." ${ }^{114}$ Although he composed with the intent to promote the music of Puerto Rico, cultural nationalism as well as his instinctive representations of musical elements such as timbre, seemed to be a part of how he valued his existence as a Puerto Rican. These decisions or behaviors were from a culmination of cultural beliefs that stem from the island's resistance to a loss of whatever identity they held dear within their cultural expression.

Campos Parsi's life experiences as a whole shaped his musical choices and output. It was not so much a choice, rather a natural progression of logical, intentional, and unintentional decisions based on his combined life experiences and environment. His training only helped him achieve the goal to express these ideas in what he regarded as the high art form which commanded attentive listening on the part of the audience.

While Campos Parsi was considered a Nationalist composer, he did not compose in this manner for the entirety of his life. What makes a composer a nationalist is the use of folk elements, scenes of a nation in daily life or in their environment, as well as the musical representation of a nation's identity and its people (Halsall, 1998). Nationalist composers such as Antonín Dvořák, Aaron Copland, Modest Mussorgsky, and Frédéric Chopin were considered representatives of their nations as composers. Campos Parsi appreciated the work of these

114. Alan Merriam, The Anthropology of Music. (Evanston: Northwestern University Press, 1964), 146 
composers, but he delved into other forms of composition that had nothing to do with Puerto Rican folkloristic culture, such as electronic music, for a short time. ${ }^{115}$

The reason why he was considered a Nationalist composer may have been because of his dedication to the promotion of Puerto Rican art music. This occurred while other composers embraced atonality and $20^{\text {th }}$ century experimental techniques. Although some composers on the island may have been affected by social responses to politics, Campos Parsi's purpose in life was to uphold the cultural spirit of Puerto Rico and to be its cultivator and protector. ${ }^{116}$ It appears as though his mission was twofold: to promote compositions from Puerto Rican composers on the island and to help elevate Puerto Rico's contributions to the world stage of Western art music.

In conclusion, the field of education deals with learning by abstract and concrete means. In the non-tangible, non-tactile, abstract world we turn to conceptualization. For example, we can learn to play a piano because the piano is concrete; we can touch it. But to learn something that has no physical form, something as abstract as culture, we conceptualize it. Culture is a concept that must be conceptualized. While piano, for instance, is learned via physical interaction, musical interpretation is dependent on the process of thinking through a concept or concepts through conceptualization. Thus, to acquire knowledge of one's own culture from birth via enculturation, the process is contingent upon environmental factors that the individual will conceptualize or process over time. This process seems to have directly affected the creative output Hector Campos Parsi's songs under analysis in this paper.

115. Although composers such as Rafael Aponte Ledée were exploring serialism and aleatory, Campos Parsi did not make that his style of expression.

116. Campos Parsi, $41-42$ 
When identifying the symbol of Puerto Rico's musical culture, it is necessary to include various musical forms in both art music and popular music because doing so can paint a better picture of the variety of musical expressions and the complexity of its identifying characteristics. Puerto Rico's quest for a cultural identity is ongoing. The abundant variety of musical and artistic contributions of the Puerto Rican people offer a lens from which to examine their cultural heterogeneity and uniqueness. These contributions should be taken into consideration when examining the works of Puerto Rican composers. 


\section{Implications for Teaching and Learning}

Currently, some programs appear to be more inclusive of Spanish vocal literature as more singers add Spanish-language art songs and arias on their recital programs than they have since 2000. It is important to take into account that, Puerto Rico for example, has contributed 100 years of music that is not being explored. Since Puerto Rico is part of the United States, it should be included. The same could be true of Native American composers who have also contributed to art song literature. Further research in this direction could present a solid case for inclusion in the general curriculum.

Nevertheless, our voice programs may need to reexamine the scope and sequence of their core voice curriculum. It is possible that some instructors may argue that our curriculum represents what students need in order to be effective singers. As more music from Latin American composers enters the commercial space, singers will need to know how to approach the language, as well as its variances. They would benefit from studying art songs and opera literature in Spanish so they can compete with others for work while they are in school and when they graduate.

The art songs of Puerto Rico, particularly those discussed in this paper, are worthy of attention and performance. The Spanish language also varies by region which is why students should study Spanish diction and carefully observe regional dialects through study. These songs should be incorporated into either a study of Spanish language art songs incorporating Latin and Iberian contributions, or within the studies of Latin American and US American music combined. Puerto Rico is a commonwealth and part of the United States, and the island's music history is part of American history. It deserves recognition and inclusion. 
As stated in the introduction, it is my hope that this paper will persuade readers - voice teachers and singers in particular - to accept this repertoire as part of the standard repertoire for undergraduate and graduate voice students. We can reevaluate programs to include Spanish diction and vocal literature from various Spanish-speaking countries as a standard practice at undergraduate and graduate levels. This paper covered the contribution of one Puerto Rican composer, but it could serve as a template for examining the works of other Latino and Iberian composers. If students wish to analyze the music, they should consider taking into account the cultural influences of a composer's life and environment. It may help them understand the music in a manner that will enhance their interpretation of it. 


\section{BIBLIOGRAPHY}

Archivo Virtual del Instituto de Cultura Puertorriqueña. "Interpreta Margarita Castro Alberty", La Canción de Arte Puertorriqueña. Serie de Música Contemporanéa, ICP / C-22, Vol. 4. Accessed August 24, 2019. https://www.archivoicp.com/search?q=margarita\%20castro.

Barton, Georgina. "The Relationship Between Music, Culture, and Society: Meaning in Music: Implications for Classroom Practice." (August 14, 2018): 1-5. https://link.springer.com/chapter/10.1007/978-3-319-95408-0_2.

Batista, Gustavo and Héctor Campos Parsi. Entrevista a Héctor Campos Parsi, (September 12, 1984). Accessed August 10, 2019, http://www.gustavobatista.com/entrevista/hector_campos_parsi.pdf

Campos Parsi, Héctor, William Scribner, and Adam Lesnick. Sonetos Sagrados $=$ Sacred sonnets: for woodwind quintet and voice (soprano or tenor). Richmond, VA: International Opus, 2001.

Campos Parsi, Héctor. La Gran Enciclopedia de Puerto Rico: Música en Puerto Rico. Volume 7, 13-360, 1976. Accessed August 10, 2019. https://archive.org/details/lagranencicloped07madr/

Campos Parsi, Héctor. 1953. Canciones de cielo y agua. Paris: [n.p.], 1953.

Caso, Fernando H. "Héctor Campos Parsi in the history of twentieth-century music of Puerto Rico.” Thesis., University of Indiana, 1972.

Conservatorio de Música de Music of Puerto Rico, "History.” Accessed October 31, 2019. cmpr.edu/cmpr/historia/

Corrigall, Kathleen A., and Laurel J. Trainor. "Musical Enculturation in Preschool Children: Acquisition of Key and Harmonic Knowledge." Music Perception: An Interdisciplinary Journal 28, no. 2 (December 2010): 195-200. doi:10.1525/mp.2010.28.2.195.

Cruz Santos, Martín. “Operation Serenity”, Enciclopedia de Puerto Rico. November 11, 2015. https://enciclopediapr.org/en/encyclopedia/operation-serenity/.

Darder, Antonia. "Pedro Albizu Campos". Encyclopaedia Britannica. September 8, 2019. https://www.britannica.com/biography/Pedro-Albizu-Campos.

Diaz, Edgardo Diaz. "Puerto Rican affirmation and denial of musical nationalism: the cases of Héctor Campos Parsi and Aponte Ledée." Latin American Musical Review / Revista De Música Latinoamericana 17, no. 1 (1996): 1-20. doi:10.2307/780335. 
Dower, Catherine. Puerto Rican Music Following the Spanish-American War: 1898, the Aftermath of the Spanish-American War and Its Influence on the Musical Culture of Puerto Rico. Landham, Md: University of America Press, 1983.

Echevarría, Roberto and Enrique Pupo-Walker. The Cambridge history of Latin American Literature. Cambridge New York, NY: Cambridge University Press, 1996.

Elliott, David J. "Music as Culture: Toward a Multicultural Concept of Arts Education." Journal of Aesthetic Education 24, no. 1 (1990): 147-66. doi:10.2307/3332862. Accessed August 12, 2019. https://www.jstor.org/stable/3332862

Freeman, John W. "Héctor Campos Paris", cd jacket of Bronx Arts Ensemble, p, 4. New York: New World Records, 1989

Georges, Patrick. Western Classical Music Development: a statistical analysis of composer's similarity, differentiation and evolution. Scientometrics, 112 (1): 21-53. Published

González Miranda, Francisco. "Music in the Films of the Community Education Division." Enciclopedia de Puerto Rico. September 12, 2014. Accessed October 1, 2019. https://enciclopediapr.org/en/encyclopedia/music-in-films-of-community-educationdivision/.

Grupo Editorial EPRL. “Amaury Veray Torregrosa. September 3, 2014. Accessed August 10, 2019. https://enciclopediapr.org/en/encyclopedia/veray-torregrosa-amaury/ online April 22, 2017. PMID: 28725093 https://www.ncbi.nlm.nih.gov/pmc/articles/PMC5486899/\#!po=0.354610.

Instituto de Cultura Puertorriqueña, "General Information.” Accessed January 20, 2017. https://www.icp.pr.gov/archivo-general/

Halsall: Internet History Sourcebooks Project, Fordham University. Accessed September 5, 2019. https://sourcebooks.fordham.edu/mod/NATMUSIC.asp.

Henahan, Donal. “Music View: Does A Composer's Life Affect His Music?” The New York Times, February 19, 1984, Section 2, 19. https://www.nytimes.com/1984/02/19/arts/music-view-does-a-composer-s-life-affect-hismusic.html

Jan, Steven. The Memetics of Music: A Neo-Darwinian View of Musical Structure and Culture. New York: Routledge, 2016.

Merriam, Alan. The Anthropology of Music. Evanston; Northwestern University Press, 1964.

McAdams, Stephen. "Timbre as a Structuring Force in Music." Acoustical Society of America, Vol. 19, 035050. (2013): 1-6. doi: 10.1121/1.4799391. Accessed November 19, 2019.https://asa.scitation.org/doi/pdf/10.1121/1.4799391. 
Méndez-Méndez, Serafín, and Ronald Fernandez. Puerto Rico Past and Present: an encyclopedia. California: Greenwood, an imprint of ABC-CLIO, LLC, 2017. http://www.credoreference.com/book/greenwoodqji.

Montalvo, José A. Héctor Campos Parsi His Life and Music: A Biographical Study with an Analysis of Four Selected Works. PhD diss. New York: New York School of Education, Health, Nursing and Arts Professions, 1992.

Morales, Gary. "History of Puerto Rican Music." Enciclopedia de Puerto Rico. September 4 2014. Accessed August 10, 2019. https://enciclopediapr.org/en/encyclopedia/history-ofpuerto-rican-music/.

Morrison, Steven J., Steven M. Demorest, and Laura A. Stambaugh. "Enculturation Effects in Music Cognition: The Role of Age and Music Complexity." Journal of Research in Music Education 56, no. 2 (2008): 118-29. Accessed August 16, 2019. www.jstor.org/stable/40343719

Sanz, Trinidad Padilla de (Hija del Caribe). "Notas Musicales", Puerto Rico Musical 1, no. 1 (February 15, 1906): 5-6. Quoted in Donald Thompson, Music in Puerto Rico: A Reader's Anthology, “The Twentieth Century”, Maryland: Scarecrow Press, Inc., 2002.

Tanglewood Music Center. "Tanglewood Music Center yearbook" 1949. Accessed October 12, 2019.https://archive.org/details/tanglewoodmusicc1949bost/page/n1.

Thompson, Donald and Schwartz, Francis. Concert Life in Puerto Rico, 1957-1992: Views and Reviews, p. 537. University of Puerto Rico, San Juan, P.R.: 1998.

Thompson, Donald. Editor and translator. Music in Puerto Rico: A reader's anthology. Lanham, MD: Scarecrow Press, 2002.

Torres, George. Encyclopedia of Latin American popular music. 2015. http://www.credoreference.com/book/greenwoodegi.

Torres, Jaime Torres. "Batista and Borinquen's Music History", Fundación Nacional Para La Cultura Popular. Accessed November 30, 2019. https://prpop.org/2016/09/batista-y-lahistoria-musical-de-borinquen/.

Wagenheim, Kal and Olga Jimenez de Wagenheim. Puerto Rico: A Documentary History. $5^{\text {th }}$ ed. Markus Wiener Publishers: Princeton, NY, 1999. 